\title{
James Madison and Public Choice at Gucci \\ Gulch: A Procedural Defense of \\ Tax Expenditures and Tax Institutions
}

Edward A. Zelinsky ${ }^{\dagger}$

\section{INTRODUCTION}

Few academic doctrines can claim the intellectual and political success of tax expenditure analysis. In roughly a generation's time, ${ }^{1}$ Professor Surrey's procedural and substantive critique of tax subsidies has become entrenched in the law school curriculum ${ }^{2}$ and in legal scholarship. ${ }^{3}$ More impressively, the tax expenditure concept has been enshrined in federal law ${ }^{4}$ and become part of the daily discourse of the national budget process. ${ }^{5}$

In earlier articles, I have revisited the substantive tax expenditure indictment of tax subsidies to suggest that the Surrey school's invariable preference for direct government outlays is misplaced. While the classification of particular features of the Internal Revenue Code as either normative or subsidizing is critical to tax expenditure analysis, that classification cannot

$\uparrow$ Visiting Professor of Law, Yale Law School; Professor of Law, Benjamin N. Cardozo School of Law, Yeshiva University. I would like to express my thanks to those who commented on prior drafts of this Article: Professors Stewart E. Sterk, Paul M. Shupack, Robert C. Ellickson, Jerry L. Mashaw, Daniel A. Farber, Douglas Rae and Fred S. McChesney and the participants in a Yale Law School faculty seminar. I also benefited from the research of Adam Frank, Yale Law School Class of 1993.

I. Professor Surrey developed the fundamental premises of tax expenditure analysis-the classification of tax provisions as normative or subsidizing and the equivalence of the latter to direct spending-during the later years of the Johnson Administration when serving as the Assistant Secretary of the Treasury for Tax Policy. As an academic matter, his initial, influential statement of the ideas that became tax expenditure analysis occurred in the late 1960's. See STANLEY S. SURREY, Tax Expenditures and the Budget, in TAX POLICY AND TAX REFORM: 1961-1969, SELECTED SPEECHES AND TESTIMONY OF STANLEY S. SURREY 573 (William F. Hellmuth \& Oliver Oldman eds., 1973); Stanley S. Surrey, Tax Incentives as a Device for Implementing Government Policy: A Comparison with Direct Government Expenditures, 83 HARV. L. REV. 705 (1970) [hereinafter Surrey, Tax Incentives].

2. See, e.g., William A. KLen ET AL., Federal InCOME TAXation 24 (8th ed. 1990).

3. See, e.g., JOSEPH M. DODGE, THE LOGIC OF TAX: FEDERAL INCOME TAX THEORY AND POLICY 290 (1989). This is not to imply that the academic influence of tax expenditure analysis has been limited to legal scholarship. See JOHN F. WITTE, THE POLITICS AND DEvelOPMENT OF THE FEDERAL INCOME TAX 269 (1985).

4. See 2 U.S.C. $\$ 640(c)(3)$ (1988) (adopted as part of Congressional Budget and Impoundment Control Act of 1974, requiring promulgation of annual tax expenditure budget).

5. See, for example, the discussion of tax expenditures in President Bush's 1993 budget proposal. Excerpts From President Bush's FY 1993 Budget Proposal, Submitted to Congress January 29, 1992, Daily Tax Rep. (BNA) Special Supplement No. 2, at S-57 (Jan. 30, 1992). 
always be made with confidence. ${ }^{6}$ Moreover, the substantive case against tax subsidies depends upon a comparison of such subsidies with an idealized vision of direct spending. ${ }^{7}$ In theory, tax expenditures can be designed as efficiently and progressively as programs using direct governmental outlays. On the other hand, if we compare the messy realities of tax preferences with the equally unattractive realities of direct expenditure programs. tax preferences emerge better than most of the Surrey school would acknowledge. ${ }^{8}$ Indeed, in particular cases, a tax subsidy may be more efficient than an equivalent direct spending program because such a subsidy uses the pre-existing tax system to communicate federal policy at relatively low marginal cost. ${ }^{9}$ Thus, as a matter of substantive policy, a certain agnosticism is in order: in some instances, direct government outlays will be preferable to comparable tax expenditures; in other cases, a subsidy through the Internal Revenue Code will be the preferred means of implementing federal policy.

In this Article, I revisit the procedural aspects of the tax expenditure critique to argue against that critique insofar as it is premised on the asserted expertise of direct expenditure institutions. The core of my argument is that the institutions formulating and administering tax policy are more competitive and visible than their direct outlay counterparts because tax institutions are subject to more numerous and diverse constituencies than the specialized, limitedclientele organizations that design and implement direct government spending. Tax institutions, because of their greater visibility and more competitive nature, are less susceptible to interest group capture and possess greater legitimacy under pluralist criteria than their direct expenditure equivalents. This perspective leads to a form of agnosticism as well: the congressional

6. In particular, I have argued that the Code's present treatment of qualified plans is consistent with the terms of a normative income tax and is therefore undeserving of characterization as a tax expenditure. See Edward A. Zelinsky, The Tax Treatment of Qualified Plans: A Classic Defense of the Status Quo, 66 N.C. L. REv. 315 (1988) [hereinafter Zelinsky, Classic Defense]. I have also criticized the reflexive classification as a tax subsidy of the deduction for certain state and local taxes. See Edward A. Zelinsky, The Deductibility of State and Local Taxes: Income Measurement, Tax Expenditures and Partial, Functional Deductibility, 6 AM. J. TAX POL'Y 9 (1987) [hereinafter Zelinsky, State and Local Taxes]. Professor Kahn has similarly suggested that accelerated depreciation may be consistent with the provisions of a normative income tax. See Douglas A. Kahn, Accelerated Depreciation-Tax Expenditure or Proper Allowance for Measuring Net Income?, 78 MICH. L. REV. 1 (1979). Professor Stein, on the other hand, has vigorously contested my views, defending the classification as a tax subsidy of the Code's qualified plan provisions. See Norman P. Stein, Qualified Plans and Tax Expenditures: A Reply to Professor Zelinsky, 9 AM. J. TAX POL'Y 225 (1991); Edward A. Zelinsky, Qualified Plans and Identifying Tax Expenditures: A Rejoinder to Professor Stein, 9 AM J. TAX POL'Y 257 (1991) [hereinafter Zelinsky, Rejoinder]; see also Douglas A. Kahn \& Jeffery S. Lehman, Tax Expenditure Budgets: A Critical View, 54 TAX NoTES 1661, 1664 (1992) ("IV]ery few items fit neatly into" categories of normative and subsidizing); Victor Thuronyi, Tax Expenditures: A Reassessment, 1988 DUKE L.J. 1155, 1156 (1988) (introducing "substitutable tax provisions" concept).

7. Edward A. Zelinsky, Efficiency and Income Taxes: The Rehabilitation of Tax Incentives, 64 TEX. L. REV. 973 (1986).

8. For example, the complexity of direct expenditure programs places the complexities of tax subsidies in a different light. Edward A. Zelinsky, The Tax Reform Act of 1986: A Response to Professor Yorio and His Vision of the Future of the Internal Revenue Code, 55 FORDHAM L. REV. 885, 892-93 (1987).

9. Zelinsky, supra note 7 , at 1010 . 
committees that design and the administrative agencies that implement tax subsidies may, in particular cases, be preferable to their direct expenditure counterparts.

To develop my argument, I will initially review the procedural case against tax preferences and will then contrast the expertise-based premise of this perspective with the Madisonian/public choice/pluralist tradition in American political thought, a tradition that focuses, not upon the asserted proficiencies of policymakers, but upon the interplay of competing interest groups in the political process. I will then elaborate my argument about the differences between the administrative agencies and congressional committees that formulate and implement direct expenditure programs and the equivalent tax organizations. As part of this argument, I will present the results of empirical research in support of my position-research focusing upon patterns of congressional campaign contributions, relative quantities of largesse channeled through the direct expenditure and tax systems, and patterns of press coverage of tax and direct expenditure organizations. ${ }^{10} \mathrm{I}$ will then consider possible objections to my defense of tax institutions as more pluralist and less capturable as well as necessary qualifications of and refinements to my thesis, and will conclude by discussing the tax policy and constitutional implications of my analysis.

Let me emphasize at the outset, what I am not saying: I am not suggesting that the institutions that design and implement the tax law are immune from capture by interest groups or perfectly implement the pluralist model of democracy. I am not declaring that, in all cases, a tax subsidy is better designed and administered than its direct expenditure counterpart or that the interplay of interest groups mechanically dictates legislative and administrative outcomes: ideology, accident, history, inertia, partisanship, public opinion, cultural norms, bureaucratic aggrandizement, the idiosyncrasies of legislators and the legislative process, and the personalities and proclivities of individual decisionmakers, as well as their concern for the public interest, all affect the outcomes of political and administrative processes. The procedures by which taxes are designed and administered are not ideal or pretty or inhabited exclusively by the pure of heart.

I am suggesting that, in the long term, institutional differences of the sort I explore below do systematically affect legislative and bureaucratic outcomes for better and for worse. A defense of the tax system along these lines constitutes an important counterweight to the widespread, contemporary disillusionment with that system. ${ }^{11}$

10. This research is presented and discussed more fully in the Appendix, infra p.1195.

11. The analysis developed here contrasts with my earlier views on this subject. In particular, I did not appreciate the greater susceptibility to capture of the specialized nontax committees of Congress and the corresponding advantages of the tax-writing process. For my earlier comments on the issue of capture, see Edward A. Zelinsky, Greenmail, Golden Parachutes and the Internal Revenue Code: A Tax Policy 


\section{THE PROCEDURAL CASe Against TAX EXPENDITURES: THE EXPERTISE OF DIRECT EXPENDITURE INSTITUTIONS}

In its original incarnation, the procedural critique of tax subsidies embodied two basic concerns: that such subsidies, undisclosed in the federal budget, were not subject to the same scrutiny as direct monetary expenditures, and that such subsidies, designed and implemented by congressional tax-writers and the Department of the Treasury, were not formed or administered using the specialized subject matter expertise of the other committees of Congress and the nontax executive departments.

The first part of this critique gave rise to the proposal for the tax expenditure budget, the annual identification, as part of the federal government's regular budgetary process, of the subsidies contained in the Internal Revenue Code and of their projected costs. Today, the preparation of such a budget is required by statute. ${ }^{12}$ Not surprisingly, much political and academic attention has been devoted to determining the items properly included in the yearly tax expenditure budget and the revenues foregone as a result of such items. ${ }^{13}$

While the tax expenditure school had quick (and, I think, useful) ${ }^{14}$ success in persuading Congress of the need for an annual tax expenditure budget, it has had less impact vis-à-vis the second element of its procedural critique, i.e., the failure, in the design and implementation of tax preferences, to utilize the subject matter expertise of the nontax congressional committees and executive departments. Professor Yorio expressed the concern in these terms:

The process by which tax subsidies are enacted and administered also increases the risk that they would fail a cost-benefit test. To begin with, a tax subsidy enters the Code after review primarily by the House Ways and Means Committee and the Senate Finance Committee. Charged principally with matters of tax and finance, both committees are usually less informed about the specifics of the problems justifying government intervention than those Congressional committees that grapple regularly with the problems. Moreover, the duty of administering tax subsidies is left to the Internal Revenue

Critique of Sections 280G, 4999 and 5881, 35 VILL. L. REV. 131, 191-92 (1990).

12. The Congressional Budget Act of 1974, mandating the preparation of an annual tax expenditure budget, Congressional Budget and Impoundment Act of 1974, Pub. L. No. 93-344, $\$ 308,88$ Stat. 297, 313 (1974) (current version at 2 U.S.C. $\$ 639$ (c)(3) (1988)), was adopted four years after Professor Surrey's article appeared in the Harvard Law Review. Surrey, Tax Incentives, supra note 1.

13. See, e.g., Kahn \& Lehman, supra note 6; Michael J. McIntyre, A Solution to the Problem of Defining a Tax Expenditure, 14 U.C. DAVIS L. REv. 79 (1980); Zelinsky, Rejoinder, supra note 6; Zelinsky, Classic Defense, supra note 6; Zelinsky, State and Local Taxes, supra note 6.

14. Despite my reservations about the classification of items as normative or subsidizing, I believe that on balance, the tax expenditure budget has improved the quality of tax discussion and policymaking, forcing greater scrutiny of the Code and proposals to change it. 
Service (IRS), which generally has no particular expertise with respect to the problem that the preference was enacted to remedy. Although it may be theoretically possible for the relevant tax committees and the IRS to obtain and digest the information required to make a rational cost-benefit decision about a specific tax expenditure, the process of education and learning is likely to be haphazard and incomplete. As a practical matter, it is virtually impossible for two congressional committees and one administrative agency to master the plethora and diversity of proposals for using the Code to accomplish societal goals. ${ }^{15}$

From one vantage point, this critique is easily remedied by making the enactment and implementation of tax preferences a joint undertaking of the relevant tax and nontax institutions. Subsidies implemented through the Code can, before or after passage by the Ways and Means and Finance Committees, be submitted to additional expert review by the proper subject matter committees of Congress. ${ }^{16}$ Congress can-and, on occasion, does-provide for the joint administration of particular tax subsidies by the IRS and the appropriate nontax administrative agency, ${ }^{17}$ thus utilizing the specialized expertise of the nontax agency in the implementation of the tax subsidy. ${ }^{18}$

15. Edward Yorio, Equity, Efficiency, and the Tax Reform Act of 1986, 55 FORDHAM L. REV. 395, 425 (1987) (citations omitted); see also STANLEY S. SURREY \& PAUL R. MCDANIEL, TAX EXPENDITURES 10607 (1985) (The Treasury and IRS typically "lack expertise on the subject matter" of tax expenditures as do "the tax committees" of Congress.); E.C. Lashbrooke, Jr., An Economic and Constitutional Case for Repeal of the I.R.C. Section I70 Deduction for Charitable Contributions to Religious Organizations, 27 DUQ. L. REV. 695, 700 (1989) (Tax expenditure "activity unnecessarily burdens the Service . . . in areas in which the Service does not have the requisite expertise"); Thuronyi, supra note 6, at 1161 ("Tax expenditures .... are administered by the Internal Revenue Service (IRS), an agency unfamiliar with the substantive problems addressed by subsidies ...."); Edward Yorio, The Future of Tax Reform: A Rejoinder to Professor Zelinsky, 55 FoRDHAM L. REV. 899, 904 (1987) ("[U]ntil Congress actually reforms its procedures [to provide for nontax committee review of proposed tax expenditures] tax incentives are unlikely to be as carefully crafted and controlled as direct subsidies."). For an earlier statement of Professor Surrey's procedural concerns, see STANLEY S. SURREY, PATHWAYS TO TAX REFORM, THE CONCEPT OF TAX EXPENUITURES $141-46$ (1973).

16. See Zelinsky, supra note 8 , at 891. Such joint review assumes agreement as to the identification of tax provisions that are subsidizing rather than normative.

17. For example, under the low-income housing credit established in Section 42, important administrative functions are assigned to the U.S. Department of Housing and Urban Development and the U.S. Department of Agriculture. See I.R.C. $\$ \$ 42(d)(5)(C)(i i), 42(d)(6)$ (1992). Similarly, state employment agencies play significant roles in the implementation of the targeted jobs credit of Section 51 , while the Department of Agriculture has important responsibilities in the administration of Section 126, which excludes from income certain benefits received from government programs. See I.R.C. \$\$ 51(d), 126(b) (1992).

Such joint administration by tax and nontax agencies is not without its problems. Dissatisfaction with the joint implementation of federal pension policy by the Departments of the Treasury and Labor has led to repeated complaints including suggestions for the creation of a single, pension-related agency at the national level. See, e.g., Joanna Richardson, Aging Committee Seeks Coordinated, 'Proactive' Approach To ERISA Enforcement, 54 TAX NOTES 678 (1992). The point, however, remains: if we conclude that tax expenditures should be administered using the expertise of nontax agencies, the expenditures can be designed in a fashion providing for joint implementation.

18. Such cooperation by tax and nontax institutions looks less benign to me now in light of the problems of capture discussed later in this Article. See infra notes 43-47,64-71 and accompanying text. Professors Surrey and McDaniel reject the joint development and implementation of tax expenditures on 
More generally, the expertise critique of tax expenditure institutions can be understood as a tactical argument in an effort to purify the tax code, a classic lawyers' strategem of talking procedure to avoid substance. The critique of tax organizations and their alleged subject matter deficiencies provides a procedural rationale for abolishing any particular tax subsidy without addressing the subsidy's substantive merits, assuring the proponents of the subsidy that their concerns can be addressed by the mandarins of the directspending system.

The expertise indictment of tax preferences can also be understood as a normative prescription for efficacious government under the assumption that a decision has been made to commit a given number of dollars to a particular area. Presuming a determination to spend a specific amount of money to address a specific problem, that money, the argument suggests, will be allocated and disbursed more efficiently and professionally by the knowledgeable personnel of direct-spending institutions rather than the generalists of the tax system. Paradoxically, the expertise critique can be viewed simultaneously as a formula for reducing government outlays: the specialists inhabiting direct expenditure organizations will more effectively scrutinize, and therefore eliminate, unwarranted spending within their respective jurisdictions than will less informed tax decisionmakers. The paradoxical nature of tax expenditure analysis is an important element in its success; the analysis both assures proponents of active government that public outlays can be made through direct spending and appeals to conservatives as a formula for reduced government activity. ${ }^{19}$

On the most fundamental level, the expertise critique of tax expenditures invokes the important notion in American political culture that disinterested, "trained, nonpartisan experts [can] best manage the subtle and difficult social questions of the modern world." ${ }^{\text {"20 }}$ From this vantage point, Professor Surrey's procedural case for the subject matter proficiency of nontax institutions is an appeal to the managerial and technocratic values underpinning such expertoriented institutions as civil service systems, independent regulatory agencies, and municipal governments run by city managers. Professor Surrey's perspective is thus firmly rooted in the tradition of Progressive, New Deal, and good government reformers who placed great confidence in the processes and outcomes of professional decisionmaking-a tradition which, in Professor

\footnotetext{
the ground that such cooperation is likely to be "incomplete and cumbersome ... produc[ing] delay and confusion rather than cooperative activity." SURREY \& MCDANIEL, supra note 15, at 106-107. Skepticism about the potential for cooperation among tax and nontax institutions was, from the beginning, part of Professor Surrey's critique of tax expenditures. See SURREY, supra note 15, at 141-42 (cooperation between Congress' tax and nontax committees "is awkward and leaves unanswered questions").

19. Zelinsky, supra note 8, at 888 n.26; Zelinsky, supra note 7, at 1021 .

20. LEWIS L. GOULD, REFORM AND REGULATION, AMERICAN POLITICS FROM ROOSEVELT TO WILSON 210 (2d ed. 1986).
} 
Banfield's apt, but wary, description, seeks "to replace politicians with experts."21

\section{Interest Group Theory: Madison, PluRAlism, Public Choice, AND MONITORING POLITICAL AGENTS}

James Madison, in contrast, was skeptical of institutional arrangements that presume "[e]nlightened statesmen will . . a always be at the helm" of government. ${ }^{22}$ For Madison, self-government is not a matter of entrusting public authority to experts but, rather, of coping with the inevitable "spirit of party and faction in the necessary and ordinary operations of government."23 That spirit, if uncontrolled, leads to instability, oppression, and disregard of "the public good . . . in the conflicts of rival parties."24

For Madison, the ideal polity was competitive with a "variety of parties and interests." ${ }^{25}$ A diversity of interests, Madison argued,

make[s] it less probable that a majority of the whole will have a common motive to invade the rights of other citizens; or if such a common motive exists, it will be more difficult for all who feel it to discover their own strength and to act in unison with each other. ${ }^{26}$

In much contemporary discussion, ${ }^{27}$ Madison's concerns are echoed in the vocabulary of public choice, the academic discipline which "employs the analytic tools of economics" 28 to understand and evaluate political processes. An important variant of this perspective "conceives regulation as a service supplied to effective political interest groups." ${ }^{29}$

21. EDWARD C. BANFIELD, HERE THE PEOPLE RULE 170 (2d ed. 1991). In a similarly skeptical vein, Professor Wildavsky has discussed the premise of expert decisionmaking which underpinned the executive budget movement. AARON B. WILDAVSKY, THE NEW POLITICS OF THE BUDGETARY PROCESS 53 (1988).

22. See THE FEDERALIST No. 10, at 80 (James Madison) (Clinton Rossiter ed., 1961).

23. Id. at 79 .

24. $I d$. at 77 .

25. Id. at 83 .

26. Id.

27. This is not to suggest, as some of the public choice literature implies, that, between Madison and the emergence of the modern public choice school, no one recognized the importance of self-interest and clientele groups in the political process. For example, the young Oliver Wendell Holmes, Jr. observed that "in the last resort a man rightly prefers his own interest to that of his neighbors. And this is as true in legislation as in any other form of corporate action ... . The more powerful interests must be more or less reflected in legislation ....." LIVA BAKER, THE JUSTICE FROM BEACON HILL: THE LIFE AND TIMES OF OLIVER WENDELL HOLMES 214 (1991). More jocularly, but at least as seriously, Ambrose Bierce defined politics as a "strife of interests masquerading as a contest of principles. The conduct of public affairs for private advantage." Bruce Watson, Who Was it Wrote the Devil's Dictionary, SMTrHSONLAN, Mar. 1992, at 104.

28. DeNNis C. MUELleR, PUBliC ChOICE 2 (1979); see also Daniel A. Farber, Free Speech Without Romance: Public Choice and the First Amendment, 105 HARv. L. REV. 554, 555 (1991) (defining public choice theory as "the application of economics methodology to political institutions").

29. Richard A. Posner, Theories of Economic Regulation, 5 BELL J. ECON. MGMT. SCI. 335, 356 (1974). Judge Posner's article and Professor Stigler's earlier work remain the seminal statements in this 
Public choice analysis_emphasizing the rent-seeking nature of interest group activity, the incentives of political entrepreneurs to supply such groups, collective action problems which prevent the effective organization of the public at large, and the capture of legislatures and administrative agencies by organized, concentrated constituencies ${ }^{30}$-reinforces Madison's preference for competitive political processes that pit diverse and conflicting groups against one another. While it is possible in a Madisonian process for interests to respond to their situation collusively rather than competitively, attempting to satisfy their respective needs by combining into broad, mutually useful coalitions, nevertheless, insofar as the legislative or administrative environment approaches Madison's ideal, the presence of more diverse and numerous interest groups discourages such logrolling: more heterogeneous groups will find it more difficult to negotiate mutually acceptable positions for a common front; more numerous groups will find it more costly to bargain with one another and more difficult to detect and prevent defection from and freeloading on the coalition. ${ }^{31}$

In the terminology of economics, conflict among rent-seeking interest groups reduces effective demand for government subsidy because collective action costs decrease the ability of such interest groups to form working majorities in the political arena. As a matter of supply, such conflict constrains the quantum of government largesse that politicians and bureaucrats can furnish to any one group since the subsidy supplied to one contending group will be perceived as coming at the expense of the others. ${ }^{32}$

Madison's analysis of faction and the economic theory of regulation both portray organized constituencies in essentially negative terms. More benign is the pluralist perspective on interest groups, a perspective which envisions such groups as legitimate and useful participants in public life. At least as early as deToqueville, commentators have lauded the tendency of Americans to

area. See George J. Stigler, The Theory of Economic Regulation, 2 BELL J. ECON. MGMT. SCI. 3 (1971). Judge Posner does not explicitly label his approach a public choice analysis. However, his article unreservedly adopts the chief assumption of public choice theory: "the general assumption of economics that human behavior can best be understood as the response of rational self-interested beings to their environment must have extensive application to the political process." Posner, supra, at 356.

30. See James M. Buchanan \& GoRdon Tullock, THE Calculus of Consent 284-87 (1962); RICHARD A. POSNER, ECONOMIC ANALYSIS OF LAW 497-98 (3d ed. 1986). For a concise presentation of the major conclusions of the public choice literature, see William N. Eskridge, Jr., Politics Without Romance: Implications of Public Choice Theory for Statutory Interpretation, 74 VA. L. REV. 275, 285 (1988); see also, Robert D. Tollison, Public Choice and Legislation, 74 VA. L. REV. 339 (1988).

31. See, e.g., BUCHANAN \& TULLOCK, supra note 30, at 132 (labelling logrolling as "the commonly employed American term" to describe "vote-trading"); see also MUELLER, supra note 28, at 49-58. While the term "logrolling" has today come to denote cooperative behavior through the exchange of mutual support, the game of logrolling was not historically a collaborative enterprise but, rather, a sport in which the goal was to force one's opponent off the log into the water. See 2 ENCYCLOPAEDIA BRITANNICA 234 (15th ed. 1990) (describing "birling," a lumberjack sport).

32. For a good summary of the literature on interest group theory and the capture of legislative and administrative institutions, see Einer R. Elhauge, Does Interest Group Theory Justify More Intrusive Review?, 101 YALE L.J. 31, 35 (1991). 
organize themselves into voluntary associations for mutual protection and welfare. ${ }^{33}$ From the benevolent, pluralist vantage point, such associations properly represent the diverse members of the body politic and play an appropriate and constructive role in the formulation of public policy in a democratic polity. ${ }^{34}$ In Professor Lowi's terms:

Since the days of Madison the pluralist view has been that there is nothing to fear from government so long as many factions compete for its favor. Modern pluralism turned the Madisonian position from negative to positive; that is, government is good because many factions do compete for its favor. ${ }^{35}$

A comparatively new body of academic research, focusing on the principal/agent relationship, reinforces the normative preference for pluralistic political processes. Contemporary agency scholarship has largely directed its attention to monitoring issues in private sector agency relationships, in particular to the costs and difficulties of shareholder oversight of management behavior. $^{36}$ However, the concerns raised in the contemporary agency literature have, as some political scientists recognize, ${ }^{37}$ significant ramifications for the understanding of governmental processes as well: relatively closed processes, less visible to some groups or to the general public than to other groups, are more easily captured by the interests that can readily monitor those processes and therefore intelligently punish and reward such processes' decisionmakers. Conversely, more visible institutions, subject to effective oversight by numerous and diverse interests and by the public as a whole, are less prone to capture by any particular clientele since competing interests and the general public are all watching.

33. AleXIS DE TOCQUEVILLE, DEMOCRACY IN AMERICA $485-88$ (J.P. Mayer \& Max Lemer eds. \& George Lawrence trans., 1966).

34. Jack M. Beermann, Interest Group Politics and Judicial Behavior: Macey's Public Choice, 67 NOTRE DAME L. REV. 183, 188 (1991) ('“[P]luralism' ... portrays the ability of people to band together and press their interests to government as a strength of an open and democratic system.").

35. THEOUORE J. LOWI, THE END OF LIBERALISM 35 (2d ed. 1979); see also TERRY M. MOE, THE ORGANZATION OF INTERESTS (1980); WITTE, supra note 3, at 8 (defining a pluralistic system as one characterized by, inter alia, "numerous, diverse and autonomous interests," and by competition between elites over questions of public policy and access to public office); Eskridge, supra note 30, at 281 ("After World War II, the prevailing political theory was an optimistic pluralism tied to Madison's ideas."); Daniel Shaviro, Beyond Public Choice and Public Interest: A Study of the Legislative Process as Illustrated by Tax Legislation in the 1980s, 139 U. PA. L. REV. 1, 33 (1990).

36. For the seminal work of the new agency scholarship, see Michael C. Jensen \& William $\mathrm{H}$. Meckling, The Theory of the Firm: Managerial Behavior, Agency Costs and Ownership Structure, 3 J. FIN. ECON. 305 (1976). For other contributions to this scholarship, see PRINCIPALS AND AGENTS: THE STRUCTURE OF BUSINESS (John W. Pratt \& Richard J. Zeckhauser eds., 1985); Frank H. Easterbrook \& Daniel R. Fischel, Close Corporations and Agency Costs, 38 STAN. L. REV. 271 (1986); Hideki Kanda \& Saul Levmore, Taxes, Agency Costs, and the Price of Incorporation, 77 VA. L. REV. 211 (1991).

37. See Joseph P. Kalt \& Mark A. Zupan, The Apparent ldeological Behavior of Legislators: Testing for Principal-Agent Slack in Political Institutions, 33 J.L. \& ECON. 103 (1990) (hereinafter Kalt \& Zupan, Ideological Behavior]; Joseph P. Kalt \& Mark A. Zupan, Capture and Ideology in the Economic Theory of Politics, 74 AM. ECON. REV. 279, 298 (1984) [hereinafter Kalt \& Zupan, Capture]. 
Madison's view of organized constituencies, some would assert, is overly pessimistic, ignoring the possibility (and the reality) that "factions" can (and do) play a constructive role in the body politic. Similarly, economic theory in general, ${ }^{38}$ and the economic theory of regulation ${ }^{39}$ in particular, can be attacked as impoverished and incomplete, disregarding the nonmaterial motivations of groups and individuals as well as the malleable nature of human preferences: elected and appointed officials may be ideologically inspired or may seek to pursue the public welfare as they perceive it rather than to satiate special interests; human beings, individually and in association with one another, have psychological needs, religious beliefs and philosophical agendas independent of, and sometimes contrary to, their economic prosperity; individuals' preferences may be inchoate, inconsistent or incomplete. Pluralism can similarly be challenged as excessively optimistic, blind to the unpleasant realities of collective behavior in political systems. ${ }^{40}$

By way of response, I would observe that not all of these criticisms can be true all of the time: if pluralism is essentially wrong, then Madison is substantially right and vice versa. Moreover, economic models of human behavior seem particularly appropriate in the context of tax and budgetary issues which, by their nature, are primarily economic in character. Furthermore, from the perspective I advance, it is not necessary that any (or all) of the interest group theories explain exhaustively all political behavior; ${ }^{41}$ it is merely necessary to start with their common teaching that political institutions

38. See Robert C. Ellickson, Bringing Culture and Human Frailty to Rational Actors: $A$ Critique of Classical Law and Economics, 65 CHI.-KENT L. REV. 23 (1989). For an alternative response to some of the criticisms of the law and economics movement, see Susan Rose-Ackerman, Progressive Law and Economics-and the New Administrative Law, 98 YALE L.J. 341 (1988).

39. See, e.g., BANFELD, supra note 21, at 373-95 (criticizing an economic approach to politics on the grounds, inter alia, that critical economic assumptions such as "given preferences" and "profit-maximizing .. . measured in money terms" are inapplicable to political behavior); Mark Kelman, On DemocracyBashing: A Skeptical Look at the Theoretical and "Empirical" Practice of the Public Choice Movement, 74 VA. L. REV. 199 (1988); Deborah M. Weiss, Paternalistic Pension Policy: Psychological Evidence and Economic Theory, 58 U. CHI. L. REV. 1275, 1301 (1991) ("A growing body of laboratory evidence suggests that many human subjects make dynamically inconsistent choices. The most commonly accepted explanation for this phenomenon is that individual preferences are not stable.").

40. Professors Buchanan and Tullock, for example, are skeptical of the claims of pluralist commentators. See BUCHANAN \& TULLOCK, supra note 30, at 288-89 (notwithstanding the claims advanced for "pluralistic organization, ... [g]iven any collective decisionmaking rule other than that of unanimity, external costs will tend to be imposed by collective action."); see also WITTE, supra note 3, at 136 (outlining the "persistent critiques" of "the incremental/pluralist model.")

41. Indeed, most proponents of public choice theory are careful to eschew any claim that such theory, by itself, supplies a complete explanation for all political behavior. See, e.g., Farber, supra note 28 , at 557 ("Public choice theory is useful, but it cannot purport to be more than a partial explanation for political behavior . ..."); Dwight R. Lee, Politics, Ideology, and the Power of Public Choice, 74 VA. L. REv. 191, 198 (1988) ("Public choice provides only one window through which to view the political process. Any serious attempt to understand political phenomena requires the view from many windows."). By the same token, those skeptical of the economic theory of regulation are usually careful to note that the theory accurately predicts some political behavior. See Kalt \& Zupan, Ideological Behavior, supra note 37, at 128 ("ideology [as] residual" factor affecting the behavior of "(marginally) uncaptured legislators"); Kalt \& Zupan, Capture, supra note 37, at 298 ("[I]t appears that the proximity of the next election inhibits ideological shirking: senators shirk less as the policemen approach."). 
influenced by more numerous and more diverse groups are preferable to governmental organizations influenced by more limited and more homogeneous constituencies.

I would, moreover, acknowledge that not even this premise is beyond cavil. The greater independence of the Secretary of the Treasury from offsetting interest groups is not a blessing if the Secretary uses his independence to pursue questionable objects. ${ }^{42}$ Likewise, members of the Ways and Means and Finance Committees may utilize their relative freedom from particular constituencies in a fashion that makes interest group capture preferable.

It is thus important to reiterate the asymmetry between the invariable preference of the Surrey school for direct monetary expenditures and my more agnostic perspective. I am not advancing a countermyth that the processes that formulate and administer tax subsidies are invariably superior to their direct expenditure counterparts. In particular cases, the benefits flowing from the expertise of a nontax committee or of a direct expenditure department may reasonably be perceived as outweighing the correlative dangers of capture. There are also cases where susceptibility to capture is a desired quality, ensuring an intended responsiveness of governmental arrangements to a favored clientele: a grateful nation might rationally prefer veterans institutions beholden and therefore responsive to those who served in the armed services rather than veterans programs administered with less partiality by the IRS or evaluated with less solicitude by the tax committees. The larger points of this Article are that the trade-off between expertise and capture exists, that the choices this trade-off presents should not be ignored simply by asserting the superior expertise of direct expenditure institutions and that, in some instances, the greater independence and visibility of tax-writers and administrators will be preferable to the alleged subject matter proficiency of their more specialized, capturable counterparts in the direct expenditure system.

\section{THE MAdisONIAN NATURE OF TAX INSTITUTIONS}

For purposes of the Surrey critique, we can view tax and direct expenditure policy as formulated and administered in four stages. Initially, the congressional committees design and authorize programs within their respective jurisdictions. Next, the full houses of Congress act on the committees' product. Third, the President approves or disapproves the decision of the House and

42. Professor Beermann makes a similar point in connection with the frequently asserted proposition that judges ought to counteract the effects of interest group capture. Judges, he argues, may not necessarily use their independence in desirable ways. Beermann, supra note 34 , at 221-22. 
Senate. Finally, the appropriate executive department executes the program agreed upon by Congress and the President. ${ }^{43}$

The tax expenditure procedural critique is aimed at the first and fourth stages of this process. At the first stage, the critique asserts that the nontax committees of Congress possess expertise due to their specialization in particular subject matters. ${ }^{44}$ This expertise is utilized in the formulation of direct spending programs but is not used in the formulation of tax subsidies since such subsidies are designed by the Ways and Means and Finance panels, generalist bodies with less opportunity and less inclination to acquire subject matter proficiency than the narrowly focused nontax committees of Congress.

A similar analysis applies at the fourth stage of the policy process. Direct outlay programs are administered by specialized executive departments which, it is argued, develop great understanding of the programs they implement and the problems those programs address. In contrast, the Treasury and the IRS, distracted by the need to run the tax system, do not develop comparable expertise as to the subsidies confided to their administration.

The Madisonian/public choice/pluralist perspective suggests that this critique romanticizes the congressional committees that design, and the executive departments that administer, direct spending programs while ignoring the benefits of the more competitive processes through which taxes are formulated and implemented. The specialized orientation of the nontax committees and departments makes each of these institutions highly susceptible to capture by the limited constituencies affected by its comparatively narrow jurisdiction. In pluralist terms, the outcomes emanating from direct expenditure committees and departments possess less legitimacy than if more numerous and

43. I realize this highly simplified description fails to capture many nuances and complexities of the process. For example, the story of the third, presidential stage is, technically and substantively, more complicated than this: the President may veto and be overriden by both houses of Congress; his presence and preferences will affect the decisions of Congress and its committees in the two earlier stages. However, for purposes of the critique advanced by Professor Surrey and my response, this is a workable model from which to proceed. Moreover, the fourth, administrative stage of the process should not be dismissed as ministerial in nature. Executive interpretation and implementation of legislation can have important substantive implications for the parties affected by that legislation and for the public fisc. The relevant executive department is also an important actor in the initiation, review and modification of existing and proposed programs. Indeed, a department's advocacy, protection or opposition may be decisive in the legislative response to particular programs and proposals. Hence, these four stages ought to be envisioned, not in linear terms, but as a Ioop-the performance and evaluation of the executive department affecting the decisions of the committees and houses of Congress. The role of executive departments in the formulation of legislative policy is captured in the oft-used metaphor of the "iron triangle," a symbiotic relationship among congressional committees, executive departments and the relevant constituencies. See, e.g., WILDAVSKY, supra note 21, at 17 (The "mutually supportive, three-point relationship among committee members, interest groups, and agencies . . have been called iron triangles."); Beermann, supra note 34, at 192 (referring to the relationship among Congress, agencies, and groups as an "Iron Triangle"); Rudolph G. Penner, Federal Government Growth: Leviathan or Protector of the Elderly?, 44 NAT'L TAX" J. 437, 446 (1991) ("There may be a grain of truth" to the "so-called 'Iron Triangle' ....").

44. Presumably this expertise is developed by both committee staff and the members of the committee themselves. 
more diverse groups were to participate in the deliberations of these institutions.

Consider, for example, the case of agriculture. Many provisions of the Internal Revenue Code can quite comfortably be classified as subsidies for the farm industry. ${ }^{45}$ The tax expenditure procedural critique suggests that, as a matter of process, such subsidies should not be designed in Congress' taxwriting committees because these bodies lack the expertise to formulate farm policy. Instead, the agriculture committees should develop farm programs using direct outlays of government funds.

However, within the farm committees there are generally not significant countervailing pressures from nonagricultural constituencies, while in the Ways and Means and Finance panels agricultural interests are forced to contend with the competing pressures of other groups also seeking largesse from the public fisc. While the farm lobbies at times have important conflicts among themselves, they also have significant areas of agreement, particularly in comparison with the nonagricultural interests with which farm groups must contend in the tax panels. In the relatively confined settings of the agricultural committees, the limited number of farm constituencies have a comparatively easy time organizing themselves into a working majority. This contrasts with the more competitive environments of the Finance and Ways and Means Committees in which the number and heterogeneity of different interests make logrolling more difficult. In short, agricultural interests can more easily capture the agriculture committees than the tax-writing committees. In pluralist terms, the decisions of the tax panels possess greater legitimacy than those of the agriculture committees because more numerous and more diverse clienteles shape the former than the latter.

Similarly, the procedural indictment of tax preferences contends that, in the implementation of agricultural subsidies through the Code, the IRS lacks the expertise of the Department of Agriculture. However, in the administration of farm subsidies, the Secretary of the Treasury possesses greater independence from farm interests than the Secretary of Agriculture. The Secretary of Agriculture relies on farm lobbies to support his policy agenda and his department's budget. He and his subordinates may have worked with agricultural interests before appointment and may return to agriculture after government service. When a Secretary of Agriculture proposes to abolish farm subsidies, he strikes at the very rationale for his agency's existence. The Secretary of the Treasury, on the other hand, is subject to more varied and offsetting constituencies and therefore possesses greater independence from any particular constituency. He and his aides are not likely to have a prior

45. For example, a number of farm assets are singled out statutorily for particularly rapid cost recovery: certain horses, I.R.C. $\$ 168(\mathrm{e})(3)(\mathrm{A})(1992)$, certain agricultural and horticultural structures, I.R.C. $\S 168(\mathrm{e})(3)(\mathrm{D})(\mathrm{i})(1992)$, and fruit- and nut-bearing trees and vines, I.R.C. $\$ 168(\mathrm{e})(3)(\mathrm{D})(\mathrm{ii})$ (1992). Similarly, qualifying family farms enjoy estate tax benefits. I.R.C. $\$ 2032$ A (1992). 
background in agriculture or to seek agricultural employment after tenure in office. When the Secretary of the Treasury suggests the abolition of farm subsidies, he is not potentially putting himself out of a job: there will be plenty of work for the Treasury even under a Code totally purged of tax expenditures.

In the vocabulary of the economic theory of regulation, the Department of Agriculture and Congress' farm committees supply industry-specific services-agricultural subsidies - to a limited number of buyers-farm interests. In contrast, the Treasury and Congress' tax-writers supply more fungible services - tax subsidies-in a more competitive environment, distinguished by many more possible purchasers and consequent collective action problems. While the various buyers of tax subsidies may attempt to cartelize themselves, and may often succeed, in general the more competitive tax process is less conducive to such cartelization than the procedures which supply direct expenditure programs. In the more pluralistic tax context, the effective demand and the available supply of government largesse will be suppressed by the countervailing pressures of offsetting interest groups since, as a matter of demand, many heterogenous groups are less likely to form a working majority while, as a matter of supply, the benefits furnished to one group come at the expense of the others.

Admittedly, the ability of interest groups to overcome collective action problems and thus cartelize themselves into a working majority is affected by factors other than the diversity and number of those groups. Some legislators and administrators are more skillful at supplying services to organized clienteles than others; committees and agencies composed of talented political entrepreneurs are more likely to witness the formation of effective coalitions than are institutions populated by officials less adept at midwifing such coalitions. To the extent that external forces successfully constrain the largesse available to particular committees and bureaucracies, the environments within those organizations partake of zero sum games, making cooperation among interests more difficult as they are pitted directly against one another for a portion of a fixed pie. If, on the other hand, such external constraints are looser, organized interests are more likely to logroll themselves into an effective alliance to obtain additional resources for the alliance as a whole. Notwithstanding these considerations, ceteris paribus, tax committees and agencies with more numerous and diverse constituencies are less likely to be captured than direct expenditure institutions subject to fewer and more homogeneous pressures.

Indeed, contra to the Surrey critique, tax institutions, because of their greater political freedom, are better positioned than direct expenditure organizations to design and implement policies informed by expertise. The theoretical skill of direct spending organizations is of little practical significance when the clienteles of such organizations effectively dominate them and their decisions. In contrast, the counterbalancing pressures on tax 
writers and tax administrators leave them comparatively freer to make decisions informed by expertise if they are so inclined.

In advancing this analysis, I seek neither to demonize direct expenditure institutions nor to create a countermyth about the organizations that formulate and administer tax subsidies. Some members of Congress' agriculture committees are concerned, as a matter of ideology or interest, with consumer or similar issues and thus sometimes oppose certain farm lobbies; within the agricultural community, the internal divisions are sometimes bitter, leading to fierce political competition; some Secretaries of Agriculture define their roles more ideologically or view the secretaryship as their final job, freeing them to pursue more independent courses; interest groups frequently overcome collective action problems and influence tax-writing and tax administration; members of the Ways and Means and Finance Committees often do the bidding of organized constitutencies-the Code does indeed contain significant farm subsidies.

On the other hand, my analysis is an antidote to the benign, expertiseoriented argument of the Surrey school for the superiority of direct expenditure institutions, and suggests that tax institutions are better than is popularly thought or academically portrayed. Agricultural interests seem to do well in the tax-writing committees; they probably do better in direct spending contexts. Farm interests can view the Secretary of Agriculture as their natural ally; the same cannot be said of the Commissioner of Internal Revenue. ${ }^{46}$

Moreover, the trade press reinforces the greater influence of specialized clienteles in the nontax committees of Congress and in the direct expenditure departments of the executive branch by facilitating such clienteles' monitoring of the committees and departments that service them. In contrast, the incentives confronting the general press make tax institutions more visible to more diverse constituencies and to the public as a whole. ${ }^{47}$

A newspaper with a general readership is likely to allocate its reporting efforts and space to the congressional committees and executive agencies perceived as directly affecting the most potential readers: the tax panels, the IRS, the Treasury. For the general press, there is less reward in covering specialized institutions such as the agricultural committees and the Department of Agriculture, which are of immediate concern to smaller audiences. For the

46. While I have illustrated my case with the example of agriculture, I could have used the transportation industry, the natural resources lobbies, the real estate business, veterans groups or any of the interests that seek and obtain largesse from the federal fisc. Indeed, in my empirical research, I examine several of these interests and their relationships to tax and direct expenditure institutitions. See Appendix infra p.1195. In each of these cases, the specialized nontax committees of Congress are more likely to be captured by the relatively narrow interests affected by each committee's jurisdiction. Corresponding administrative agencies are similarly susceptible to capture in the implementation of direct spending programs benefiting relatively limited clienteles. However, in the processes of tax-writing and tax administration, each of these interests is more likely to find itself contending with competing groups.

47. For an empirical analysis supporting my conclusions about the trade and general press, see the discusson infra notes 129-142 and accompanying text. 
trade press, on the other hand, the incentives are the reverse. To attract and retain a specialized readership, the trade press must demonstrate a comparative advantage in reporting the news which is slighted by the general media but which is of particular importance to the members of the trade. Hence, the trade press will tend to follow more fully its specialized clientele institutions like the farm committees and the Department of Agriculture, serving as a relatively efficient means for specialized constitutencies, as principals, to oversee the performance of nontax decisionmakers, as their agents.

In short, nontax institutions are, through the trade press, more effectively monitored by the interest groups these institutions affect directly than by the public at large, while the general public can do a comparatively better job of overseeing the tax system through the general media.

Insofar as the expertise critique of tax incentives is a tactical argument advanced by those seeking purity in the Code while avoiding the substantive merits of particular tax subsidies, my argument is a tactical reply, suggesting that the tax committees of Congress, the Treasury and the IRS, more competitive, pluralist and visible environments, are procedurally superior to direct spending institutions. To the extent the expertise critique of tax subsidies is an efficiency argument for committing a given amount of spending to more knowledgeable direct expenditure specialists, my analysis suggests the generalists inhabiting tax institutions are actually better positioned to make decisions informed by expertise because of the relative political freedom engendered by the myriad countervailing constituencies of the tax system. Approaching the expertise critique as a formula for reducing government outlays via the more critical scrutiny of direct expenditure experts, my argument again suggests the critique is wrong: the legislators and administrators of direct expenditure organizations, susceptible to capture by the comparatively narrow clientele groups within their respective jurisdictions, are likely to supply greater, not lesser, spending to those groups. Finally, insofar as the expertise critique of tax subsidies reflects the technocratic and managerial values embedded in our political culture, my defense of tax processes appeals to a tradition both older and newer which focuses not upon the presumed proficiencies of decisionmakers, but upon the desirability of maximizing participation in governmental processes.

My perspective, while influenced by the economic theory of regulation, is different, in many respects, from the public choice analysis of The Tax Reform Act of 1986 advanced by Professors Doernberg and McChesney. ${ }^{43}$ Chief among their concerns is debunking the image of the 1986 Act as the triumph

48. Richard L. Doernberg \& Fred S. McChesney, On the Accelerating Rate and Decreasing Durability of Tax Reform, 71 MINN. L. REV. 913 (1987) [hereinafter Doernberg \& McChesney, Accelerating Rate of Tax Reform]; Richard L. Doernberg \& Fred S. McChesney, Doing Good or Doing Well?: Congress and The Tax Reform Act of 1986, 62 N.Y.U. L. REV. 891 (1987) [hereinafter Doernberg \& McChesney, Doing Good]. 
of public good over special interests. Professors Doernberg and McChesney find that, contrary to prevailing perception, Congress' tax-writers supplied to a variety of industries both affirmative tax benefits and protection from threatened tax disadvantages. This largesse was purchased from the members and staffs of the Finance and Ways and Means Committees through campaign contributions, ${ }^{49}$ honoraria ${ }^{50}$ and such "in-kind benefits" as free travel and entertainment. $^{51}$ In the Doernberg-McChesney saga, Congress' tax-writers were (and are) particularly entrepreneurial, sometimes creating the threat of tax disadvantages in order subsequently to sell their protection..$^{52}$

Doernberg and McChesney take direct aim at the "political fairy tale"53 of Gucci Gulch, the hallways outside the tax-writing committees densely packed with high paid, well-dressed lobbyists. The conventional story is that the denizens of Gucci Gulch lost in 1986, the general welfare prevailing over special interests in the rewriting of the tax code. ${ }^{54}$ In the spirit of public choice theory, Professors Doernberg and McChesney tell us the truth is otherwise: "tax politics as usual, with considerable sums of money changing hands," " - tax benefits supplied and purchased.

As one who believes both that the economic theory of regulation contains much truth and that the Tax Reform Act of 1986 represented a distinct improvement to the Code, I find the Doernberg-McChesney perspective a useful counterweight to the rosier stories advanced about the 1986 Act. On the other hand, I think it is helpful to take another step and compare the taxwriting processes of which Professors Doernberg and McChesney are so critical with the institutions that formulate direct government outlays. And, in such a comparison, the tax system displays distinct advantages in pluralist and public choice terms.

Madison would have been neither surprised nor particularly alarmed by Gucci Gulch and its residents: self-interest and "the spirit of faction" are inevitable in human beings, and thus in politics. In the confines of Gucci Gulch, the advocates of numerous and varied groups contended against one

49. Doernberg \& McChesney, Accelerating Rate of Tax Reform, supra note 48, at 936.

50. Id. at 940 .

51. Id. at $941-42$.

52. Id. at 944 .

53. Doemberg \& McChesney, Doing Good, supra note 48 , at 893.

54. The leading statement of this perspective is JEFFREY H. BIRNBAUM \& ALAN S. MURRAY, SHOWDOWN AT GUCCI GULCH: LAWMAKERS, LOBBYISTS AND THE UNLIKELY TRIUMPH OF TAX REFORM (1987): see also Jane Bryant Quinn, The Illusion of Tax Relief, NEwsweEK, Feb. 10, 1992, at 25 ("The gond-government types of the 1980s produced a fairer tax code by wiping out subsidies paid to dozens of special interests, and used the savings to fund lower tax rates."). A more balanced, but decidedly favorable, view of the Tax Reform Act of 1986 is provided by C. Eugene Steuerle, an influential commentator on tax policy issues and an important participant in the processes which culminated in the 1986 Act. See C. EUgene STEUERLE, THE TAX DECADE (1992). Steuerle's version of the story gives great credit to bureaucratic, academic and public interest forces concemed with tax reform. It is literally a footnote to his narrative that important industries and corporations benefited from the 1986 legislation and played important roles in securing its passage. Id. at 119 n.5.

55. Doemberg \& McChesney, Doing Good, supra note 48, at 893. 
another. If the process and results of that competition were not particularly appetizing, they were preferable to their direct expenditure equivalents. Wellpaid lobbyists, representing special interests, monitor and influence the deliberations of the nontax committees of Congress and are more likely to dominate such discussions given the less competitive, less visible environments of those specialized, limited constituency committees. From a Madisonian vantage point, the crowded halls of Gucci Gulch look safer than the quieter quarters of the Congress' agriculture committees. ${ }^{56}$

Some hint of this is to be found in the Doernberg-McChesney analysis. In that analysis, a key piece of evidence is the vast quantum of campaign contributions received from diverse sources by the members of the Finance and Ways and Means panels. ${ }^{57}$ Yet, the aggregate size of those donations and the variety of sources suggest that Congress' tax-writers are not dependent upon any particular set of contributors. For those concerned about interest group capture, such a state of affairs is preferable to the alternative: legislators heavily indebted for campaign funds to limited constituencies. The economic theory of regulation suggests that the senators and representatives who serve on nontax committees will find themselves in this unfortunate situation, highly reliant for campaign funds upon the relatively homogeneous interest groups serviced by the committees on which such legislators sit.

My analysis of the contrasting qualities of the tax and direct expenditure processes suggests a number of areas for empirical research. Foremost among these is a comparison of the largesse obtained by organized interests through direct spending with the benefits secured by those same interests through the Internal Revenue Code. If, as I suggest, it is harder for organized constituencies to capture tax processes, we would expect that such constituencies receive greater assistance from the more pliable direct expenditure institutions. On the other hand, if the Code is the preferred instrument of special interests, we would anticipate that such interests receive a higher ratio of tax benefits to direct monetary outlays.

To make this comparison, I have calculated from the regular and tax expenditure budgets for the fiscal years 1980 through 1991 the federal government's direct and tax outlays in four selected areas: agriculture, veterans, transportation and mineral resources. The detailed results are presented in Table 1 in the Appendix..$^{58}$ From 1980 to 1991, direct federal outlays for agriculture, veterans, mineral and transportation clienteles substantially exceeded the tax expenditures in these same areas. In the most recent year for which comparison can be made, fiscal 1991, for every dollar

56. While I make this observation with respect to the agriculture committees, the same may be said about any other of the specialized, nontax committees of the House and Senate.

57. Doemberg \& McChesney, Acclerating Rate of Tax Reform, supra note 48, at 936; Doernberg \& McChesney, Doing Good, supra note 48, at 900.

58. Infra p.1197. 
of tax breaks for mineral-related activity, $\$ 3.72$ was expended directly on mineral programs. In that same year, the ratio of direct veterans outlays to veterans tax benefits was $15: 1$ while the ratios of direct to tax spending for agriculture and transportation were 22:1 and 230:1, respectively.

I do not contend that the nature of the legislative and administrative processes is the only variable determining the levels of tax and direct spending in these particular categories. I do, however, conclude that the orders of magnitude in Table 1 are revealing and, to an important degree, are determined by the character of these processes. With all of the caveats and limitations associated with Table 1, its data suggest that organized constituencies obtain greater largesse through the more capturable direct expenditure processes than through the more competitive tax institutions, which is the result predicted by my analysis.

Turning to campaign contributions, I attempted to compare the relative dependence on special interests of Congress' tax-writers with the members of Congress' nontax committees; ${ }^{59}$ my results are presented in Table 2 in the Appendix. ${ }^{60}$

Acknowledging that the data in Table 2 is merely suggestive, it nevertheless strongly suggests that members of Congress' specialized, direct expenditure committees are more heavily dependent for campaign donations on the limited clienteles they serve than are the members of the tax committees who receive donations from more varied and diverse sources. For 1989-90, the average member of the Senate Agriculture Committee received in absolute dollar amounts over seven times the campaign contributions from agricultural PAC's $(\$ 93,640)$ as did the mean member of the Finance Committee $(\$ 12,222)$. Moreover, the agricultural donations received by members of the farm committee represented over ten percent of their total PAC contributions but only half that proportion (5.1\%) for members of the Finance panel.

A similar picture emerges from an examination of the transportation lobby's contributions. In absolute dollar amounts, the average member of the House Public Works and Transporation Committee received in 1989-90 almost fifty percent more from transportation PAC's $(\$ 39,440)$ than did the average representative serving on Ways and Means $(\$ 27,066)$. Even more notable is the proportionate dependence on transportation contributions of the typical member of the House Transportation Committee. For the average member of that specialized, direct expenditure body, almost twenty percent of PAC contributions came from transportation sources. In contrast, the representatives on Ways and Means received on average roughly ten percent of their PAC money from donors connected to transportation industries.

59. Information was compiled from reports filed with the Federal Election Commission and retrieved through Lexis.

60. Infra pp. 1200, 1201, 1202, 1204. 
One could reasonably characterize as substantial the donations from farm and transportation PAC's to the Finance and Ways and Means Committees. However, in the context of agriculture and transportation donations to the direct expenditure committees, Congress' tax-writers are less dependent on those interests than the legislators serving on the direct expenditure panels affecting those industries. The data in Table 2 are consistent with the argument that more specialized, limited constituency institutions (i.e., the agriculture and transportation committees) are more capturable than generalist institutions with more diverse and numerous clienteles (i.e., the tax committees).

Finally, I have tested the thesis that the general press covers more extensively the tax-related institutions of the federal government while the trade press is more oriented towards the narrowly focused entities of the direct expenditure system. The results, embodied in Table 3 in the Appendix, ${ }^{61}$ with one important exception, confirm that trade publications facilitate monitoring of direct expenditure processes by specialized clienteles while the general media provide tax institutions with broader visibility to the public as a whole. Each of the three general papers I surveyed carried more articles about Congress' two tax-writing committees than about the six selected direct expenditure committees combined. In contrast, the trade publications generally carried substantially more articles about the specialized committees affecting the publication's particular trade audience than about the tax panels.

The notable exceptions to this pattern are the two journals of the oil industry, Oil and Gas Journal and National Petroleum News, which gave more coverage to Ways and Means and Finance than to the direct expenditure committees with jurisdiction over oil. At one level, this result is not surprising; it is a commonplace that oil interests have done well for themselves in the taxwriting process. ${ }^{62}$ Whatever the reasons for this phenomenon, the oil trade press is the proverbial exception that proves the rule, monitoring Congress' tax-writing panels more heavily than the direct expenditure committees with jurisdiction over the petroleum industry and thus reflecting a different pattern from the rest of the trade publications in my sample.

\section{OBJECTIONS, QUALIFICATIONS AND REFINEMENTS}

I now want to anticipate some objections to my analysis and, where appropriate, qualify and refine my argument. First, it can be argued that, if the generalists who write and administer the tax laws are not knowledgeable about particular substantive areas of government, their lack of expertise engenders a form of capture stemming from their consequent dependence on the information provided by interest groups. Bureaucrats in direct expenditure

61. Infra p. 1206.

62. See, e.g., I.R.C. $\$ 469(c)(3)$ (1992) (exempting certain oil entities from the passive loss rules). 
agencies and members of Congress on nontax committees can, the reasoning goes, independently evaluate the data and proposals advanced by constituencies within their respective jurisdictions because such legislators and bureaucrats possess independent, countervailing expertise; tax personnel, in contrast, are more dependent upon importuning constituencies because tax personnel cannot assess the validity of what they are told. When, for example, the farm lobby furnishes data and advice to the Secretary of Agriculture or to members of Congress' agriculture committees, those individuals can evaluate that material for themselves or can turn to professional staff which can evaluate it for them. On the other hand, the argument runs, tax writers and administrators, generalists lacking specialized expertise in agriculture, are effectively captured by the farm lobby on whose information they depend.

By way of rejoinder, I should first make explicit my skepticism towards the claim of expertise for direct expenditure institutions, a skepticism in which I am not alone. Professor Wildavsky, for example, posits as a central characteristic of Congress' budget process the failure of congressmen to master the complex, technical details necessary for a thorough evaluation of the programs they oversee..$^{63}$ And once the premise of direct expenditure expertise is rejected, the asserted problem of dependence upon clientele-provided information must affect tax and nontax decisionmakers alike.

Accepting arguendo that participants in direct expenditure institutions possess cognizable expertise in the particular areas within their respective jurisdictions, tax writers and administrators can develop comparable proficiencies in specialized topics, thereby abating their informational reliance on interested lobbies. Members of the Ways and Means and Finance Committees and Treasury and congressional staff can focus upon the tax problems of particular industries, cultivating particularized expertise which enables them to evaluate independently the claims asserted and the information provided by such industries. A representative on a Ways and Means subcommittee addressing farm tax subsidies is likely to develop expertise in agricultural matters approaching that of his colleague on the farm committee. The same is true of a Finance Committee staffer overseeing tax subsidies for farming or of an IRS lawyer dealing extensively with the Code provisions affecting agriculture.

Moreover, tax policymakers, because of the competing groups within their jurisdiction, are less dependent than their direct expenditure counterparts on information provided by any particular group, since rival lobbyists in the more competitive tax environment have incentives to produce negative data to discredit competing claims.

Finally, even if direct expenditure institutions possess superior expertise in the abstract, such institutions, because of their greater proclivity towards

63. WILDAVSKY, supra note 21 , at 73-74. 
political capture, are less likely than tax organizations to make decisions actually informed by such expertise. Paradoxically, tax decisionmakers, even if theoretically less knowledgeable in particular substantive areas, are better able to make decisions informed by the expertise they do possess because their more competitive, visible environment frees them to use what expertise they have.

These observations, in turn, suggest further qualification of my thesis: as individuals and institutions in the tax process specialize to acquire proficiency in particular areas of substantive policy, the tension between capture and expertise reemerges. A Treasury lawyer who specializes in the tax problems of agriculture acquires industry-specific skills and knowledge likely to affect his views and future employment; a senator with a narrowly-focused concern about the tax problems of agriculture will develop a relationship with the farm lobby similar to that of a member of the Senate's agriculture panel. If too much substantive policy is channeled through the tax committees and the Treasury, these institutions will be forced to organize themselves internally by subject matter and thus start to resemble their more capturable direct expenditure counterparts. Confronted with overly-expansive responsibilities, the tax-writing committees will of necessity divide themselves into myriad specialized subcommittees which, because of their circumscribed jurisdictions and constituencies, will be as vulnerable to capture as the equivalent direct expenditure committees. Similarly, the Treasury, forced to cope with too many diverse, substantive areas of government, will be required to organize itself into a variety of capturable subtreasuries each with its own restricted scope and clientele. In sum, the tax system does not have infinite capacity in the generalist, multi-constituency form in which it exists today; if overutilized, the tax system will be forced to specialize in a fashion which replicates the expertise and capturability characteristics of direct expenditure institutions.

Another possible rejoinder to my analysis would suggest that the competitive nature of the second and third stages of the process for adopting direct government outlays compensates for capture in the first and fourth stages, thereby redeeming the process as a whole from the effects of special interests. The Surrey school could concede that, while the specialized committees of Congress and the nontax departments of the executive branch are highly vulnerable to capture by their respective constituencies, the problem is corrected in the deliberations of the full houses of Congress and in the President's participation in the process. In these two stages, groups which dominate their respective committees and executive departments are forced to contend with one another, ensuring the competition among interests prescribed by the Madisonian/public choice/pluralist perspective, purging the taint of capture from the system as a whole and introducing a visible, pluralist cast to the direct expenditure system. In modified form, this argument conceives of Congress' appropriations and budget panels as competitive environments which 
eliminate the effects of capture by overriding the decisions of the substantive committees that act as the advocates for their respective constituencies.

While there is an element of truth to this line of thought, there is much overstatement in it as well. Left to their own devices, the Department of Agriculture and Congress' agriculture committees would probably devote most of the federal budget to farm subsidies. The full Congress and the President obviously will not let this happen. ${ }^{64}$ However, it overstates the corrective influence of the President and Congress as a whole to conclude that they can completely eradicate the consequences of capture in the direct expenditure committees and executive departments. The consensus among scholars studying Congress is that a particular clientele's domination of a committee leads to a final outcome more favorable to that clientele. ${ }^{65}$ It is similarly a commonplace among students of American government that an interest group's control of an administrative agency affects the final outcome of the political process in ways favorable to that group. ${ }^{66}$

In terms of the stylized, four stage process,${ }^{67}$ the decisions of legislative committees set agendas and furnish resources for the debates of the full bodies in the second stage, thereby affecting the results of those second stage deliberations. ${ }^{68}$ If we view the floors of both houses as arenas dedicated to logrolling, the interest that loses in committee has no log to roll. Conversely, the interest doing well in committee has more logs to roll and, hence, is likely to emerge at the end with a larger portion of the overall largesse being dispensed. By the same token, the President's options are heavily circumscribed by the actions of the federal bureaucracy, actions which frequently constitute services supplied to clientele interests.

Ultimately, it is self-defeating for the Surrey school to claim that the capture of the direct expenditure committees is irrelevant to final legislative outcomes, for such a claim suggests that committees do not matter, a supposition that undercuts the proceduralist indictment of tax subsidies based

64. Again, I am using the agriculture committees and department only as illustrations.

65. See, e.g., Elhauge, supra note 32, at 42; Eskridge Jr., supra note 30, at 293; William H. Riker \& Barry R. Weingast, Constitutional Regulation of Legislative Choice: The Political Consequences of Judicial Deference to Legislatures, 74 VA. L. REV. 373, 387 (1988) (arguing that "committee dominance over choice in its policy jurisdiction is well-known" (citations omitted)); Kenneth A. Shepsle, Congress Is a "They," Not an "It": Legislative Intent as Oxymoron, 12 INT'L REV. L. \& ECON. 239, 245 (1992) (noting strategic position of committees in legislatures); Kenneth A. Shepsle \& Barry R. Weingast, The Institutional Foundations of Committee Power, 81 AM. POL. SCI. REV. 85 (1987) (same). For an analysis emphasizing the constraints placed by the full bodies of Congress on their committees, see Keith Krehbiel, Are Congressional Committees Composed of Preference Outliers?, 84 AM. POL. SCI. REv. 149 (1990). For an interesting interchange among these authors, see Keith Krehbiel et al., Why Are Congressional Committees Powerful?, 81 AM. POL. SCI. REV. 929 (1987).

66. An agency's success on behalf of its clientele is reciprocated by the clientele's support of the agency. Hence, these two legs of the iron triangle reinforce each other. See supra note 43.

67. See supra note 43 and accompanying text.

68. Indeed, among the most important accomplishments of public choice theorists is the rigorous confirmation of the intuitions that procedure can determine outcome and that the power to set agendas is the power to influence final results. See MUELLER, supra note 28 , at 38, 44, 57. 
on the importance of committee expertise. A critical premise of this indictment is that nontax committees do matter, that they beneficially mold ultimate legislative outcomes in accordance with their specialized knowledge. If, however, the full bodies of Congress nullify the influence of direct expenditure committees as agents for their respective clienteles, the full bodies must also eradicate the influence of those committees as expert institutions. There is, thus, no reason to prize nontax committees' expertise since, under these assumptions, it does not shape final legislative results.

It is similarly self-defeating for proponents of expertise in governmental decisionmaking to take refuge from problems of executive agency capture in the shadow of the President, the ultimate generalist in our system of government. It is a strange image of presidential leadership that presents the President as negating the executive bureaucracy's tendency to promote clientele interests, but as simultaneously constrained by the bureaucracy's capacity as a repository of specialized knowledge. More convincingly, a President who overrides agency advocacy can also override agency expertise.

For the same reasons, it is also unpersuasive for defenders of Professor Surrey's position to advance the appropriations and budget committees as the pluralist, competitive bodies that redeem the direct expenditure system from problems of capture; the appropriations and budget panels are composed of the same generalists who, as tax writers, are criticized as inexpert. Furthermore, the appropriations committees exercise authority over a limited and decreasing share of the federal government's outlays. Entitlement spending and off-budget activity, particularly the extension of federal credit, represent large and rapidly growing sectors of the national budget, outside the jurisdiction of the appropriations committees and consequently beyond any discipline those committees might impose. ${ }^{69}$

The role of Congress' budget committees is similarly quite restricted, both in theory and in practice. In theory, the budget panels merely impose overall spending limits in general areas, leaving the significant task of allocating funds within those limits to other, capturable committees. In practice, the budget committees have not even exercised effectively their theoretical authority to impose overall spending restraints. ${ }^{70}$ Moreover, the appropriations committees work through numerous specialized subcommittees, each capturable because of its relatively limited and homogeneous constitutencies. Professor Wildavsky has noted the evolution of the appropriations panels from bodies exercising "guardianship" in constraining federal outlays to advocacy institutions promoting clientele interests in the budget process, a change he attributes to

69. WILDAVSKY, supra note 21 , at 9, 12, 18, 28, 121, 268; Kate Stith, Rewriting the Fiscal Constitution: The Case of Gramm-Rudman-Hollings, 76 CAL. L. REV. 595, 605-09 (1988).

70. WILDAVSKY, supra note 21 , at 142-59. Professor Wildavsky, our leading commentator on the federal budget process, has described the "helplessness" of Congress' budget committees, concluding that these committees are "ineffective guardians" of the federal fisc. Id. at 216. 
broad transformations in American and congressional politics. ${ }^{71}$ My analysis suggests an additional cause for the appropriations panels' metamorphosis from guardians of the fisc to promoters of spending: a specialized appropriations subcommittee with authority over narrow and homogeneous interests is as susceptible to capture as the corresponding substantive committee of Congress.

In sum, those asserting the alleged expertise of direct expenditure organizations face a dilemma when they argue that other institutions-the President, the full houses of Congress, the appropriations and budget committees - eradicate special interest influence. If that argument is correct, we would expect Congress and the President to override the effects of committee and departmental expertise as well. If that argument is wrong, we are left with direct expenditure institutions, more susceptible to capture, shaping final legislative and administrative outcomes for the benefit of their respective clienteles.

Finally, let me anticipate an alternative interpretation of Table 1 which would attribute the greater largesse channeled through direct monetary outlays to technical limitations on tax subsidies rather than to the more capturable nature of direct expenditure institutions. There are inherent constraints, the argument goes, in the amount of financial assistance that can be steered through the Internal Revenue Code. Hence, high ratios of direct to tax subsidies indicate not greater political competition in tax institutions, but technical limitations in the quantum of spending which can occur through the Code.

Tax expenditure analysis correctly suggests, to the contrary, that no such limitation exists, that any direct outlay can, as a technical matter, be transformed into an equivalent tax subsidy. ${ }^{72}$ For example, Congress could, if it wanted, replace veterans' monthly benefit checks with refundable tax credits for veterans similar to the earned income credit for low income taxpayers. ${ }^{73}$ Likewise, direct cash subsidies to farmers could be converted into tax deductions which, if not immediately needed, could be sold to other taxpayers in the style of safe-harbor leasing. ${ }^{74}$ Professor Bittker has noted the interchangeability of the various features of a tax system. Writing in particular about the property tax exemption for religious institutions, but with implications beyond that specific topic, he observed: "As any first year law student knows, there is more than one way to skin a cat: deductions, credits,

71. Id. at 19,184 .

72. SURREY \& MCDANIEL, supra note 15 , at 3 .

73. See I.R.C. $\$ 32$ (1992). Indeed, the Code already provides employers with credits for hiring certain Vietnam-era veterans. I.R.C. § 51(d)(1)(C) (1992).

74. Safe-harbor leasing, a short-lived experiment, was introduced by the Economic Recovery Tax Act of 1981, Pub. L. No. $97-34 \$ 201$, 95 Stat. 172, 214 in I.R.C. $\$ 168(f)(8)$, but was then repealed by the Tax Reform Act of 1986, Pub. L. No. 99-514 $\$ 201,100$ Stat. 2085, 2121. For a discussion of the life and death of safe-harbor leasing, see MICHAEL J. GRAETZ, FEDERAL INCOME TAXATION 406-07, 653-55 (1988). 
rate schedules, etc. can be easily manipulated to take the place of a dead exemption"75 - or the place of any direct monetary outlay.

I do not contend that the dominance of direct over tax outlays, as revealed in Table 1, is solely attributable to the greater responsiveness of direct expenditure institutions to their more homogeneous and less numerous clienteles. Such responsiveness is, however, an important part of the story; given the possibilities of designing programs as either tax or direct monetary subsidies, the dominance of direct expenditures is not caused by technical limitations to the tax system but rather reflects, in large measure, the more capturable nature of the institutions of the direct expenditure system.

\section{IMPLICATIONS}

What, then, are the implications of my analysis? First, and perhaps most important, are its rhetorical ramifications. Embedded in the tax expenditure literature is an invariable preference, procedural as well as substantive, for direct government outlays. Similarly embedded in popular and academic discourse is a pronounced disillusion with the federal tax system. My analysis suggests a more balanced view of the processes for enacting and administering tax subsidies.

Both the benign explanation for the Tax Reform Act of $1986^{76}$ and the less charitable account of that legislation ${ }^{77}$ share the premise of an essentially degenerate political process, largely controlled by self-seeking interest groups serviced by willing political entrepreneurs. The two accounts differ only as to whether the tax system in 1986 experienced a brief, shining moment in which the forces of light prevailed or whether the 1986 Act represented business as usual in disguised form.

My portrayal of the tax system is more complex, positively and normatively, than either of these two perspectives. The organizations that design and implement federal taxes are not ideal or populated by the pure of heart. However, Madison, like his near contemporary Adam Smith, reminds us that perfection is not the criterion against which human institutions ought to be measured and that the utility of such institutions does not depend upon the motives or moral worthiness of those who populate them.

My argument further suggests that tax subsidies ought to be preferred to direct expenditures when there is a need for detached administration and oversight by decisionmakers less susceptible to capture. Because of his competing constituencies and functions, the Secretary of the Treasury is more likely to implement an agricultural program independently of farm lobbyists

75. Boris I. Bittker, Churches, Taxes and the Constitution, 78 YALE L.J. 1285, 1287 n.11 (1969).

76. See BIRNBAUM \& MURRAY, supra note 54; STEUERLE, supra note 54.

77. See Doernberg \& McChesney, Accelerating Rate of Tax Reform, supra note 48; Doernberg \& McChesney, Doing Good, supra note 48. 
than the Secretary of Agriculture; the Treasury is also more apt than the Department of Agriculture to disapprove a farm subsidy it administers and propose the subsidy's abolition. An important instance of such detached evaluation is the Treasury's 1984 tax reform study which recommended abolishing a variety of federal tax subsidies for, inter alia, transportation, military and mineral interests. ${ }^{78}$ It is hard to conceive of the direct expenditure departments proposing such sweeping repeal of the programs they administer. Similarly, the Ways and Means and Finance panels, because of their greater visibility and offsetting clientele pressures, are better positioned than the direct expenditure committees to oversee subsidy programs objectively.

As noted earlier, the tax system is a limited resource which, if overutilized, will start to resemble the direct expenditure institutions. ${ }^{79}$ Nevertheless, within the constraints of the system's capacity, policymakers seeking more disinterested administration and evaluation ought to follow the tax subsidy route.

My analysis also raises a cautionary note about the joint formulation and implementation of tax preferences by tax and direct expenditure institutions. ${ }^{80}$ Professors Surrey and McDaniel question the feasibility of the collaborative design and administration of tax subsidies. ${ }^{81} \mathrm{I}$, on the other hand, now see political risks to such cooperation as it potentially introduces into the tax process the enhanced influence of the affected clientele groups through their heightened leverage in the specialized committees of Congress and the nontax agencies of the executive branch. In light of these risks, it would be desirable to experiment with arrangements designed to utilize in the tax-writing process the expertise of direct expenditure institutions without importing such institutions' greater susceptibility to capture. For example, it would be useful to experiment with the composition of the Ways and Means and Finance Committees, with each substantive committee of Congress designating one member to sit simultaneously on his chamber's tax panel, serving as a conduit to the tax-writing process for the expertise of his substantive committee. When coupled with limitations on dual committee participation (e.g., no more than two senators serving simultaneously on the agriculture and finance panels), such a liaison arrangement could systematically introduce into the tax committees whatever subject matter expertise resides in the nontax panels while protecting against those panels' greater vulnerability to capture. In the

78. U.S. DEP'T OF THE TREASURY, 2 TAX REFORM FOR FAIRNESS, SIMPLICITY, AND ECONOMIC GROWTH 47, 223, 324 (1984) (proposing abolition of military-related exclusions from gross income, repeal of variety of tax preferences relative to energy and natural resources, and abolition of tax benefits for merchant marine capital construction fund).

79. See supra p.1186.

80. See the discussion infra text accompanying notes 16-18.

81. See SURREY \& MCDANIEL, supra note 15 , at 106-07. 
absence of experience with such arrangements, there is no a priori reason to prefer the direct expenditure system, the tax subsidy system, or cooperation between the two.

While my analysis is most relevant to the choices confronting tax and budgetary policymakers, it is also potentially useful to the courts. Consider, in this respect, the traditional judicial deference to administrative agencies on the grounds of agency expertise. That deference has been challenged in recent years by legal scholars portraying administrative institutions as captured by their respective clienteles and consequently unworthy of such consideration. ${ }^{82}$ If courts are prepared to categorize agencies into the expert and the captured, deferring to the former but not the latter, my analysis suggests that tax administrators belong in the expert classification because their numerous and variegated constituencies bestow upon them the political freedom to make decisions informed by expertise. The IRS and the Treasury are not immune from political pressures or interest group influence; they are, however, better positioned to resist such forces than bureaucrats dependent on limited and homogeneous clienteles.

My analysis also buttresses the distinction in the Supreme Court's Establishment Clause jurisprudence between tax and direct subsidies. An important theme of that jurisprudence is that tax provisions benefiting religious entities stand on firmer constitutional grounds than monetary outlays to such entities. While this case law has been criticized by some commentators, my argument suggests that, in light of the greater susceptibility to capture of direct expenditure institutions, the Court's First Amendment distinction between tax subsidies and direct appropriations is sound from a proceduralist perspective.

The distinction between tax and direct expenditures was initially advanced as a constitutional matter in Walz v. Tax Commission of New York, ${ }^{83}$ in which the Supreme Court upheld, over Establishment Clause objections, the constitutionality of New York's property tax exemption for churches, synagogues, and similar religious enterprises. In reaching its decision, the Walz Court drew a line between "direct allocation of public revenue" to religious associations and "indirect economic benefit" bestowed upon religious organizations via the tax system. $^{84}$

82. The article that began discussion of these issues among legal scholars was Jerry L. Mashaw, Constitutional Deregulation: Notes Toward a Public, Public Law, 54 TUL. L. REV. 849 (1980). Among other important contributions to this literature is Jonathan R. Macy, Promoting Public-Regarding Legislation Through Statutory Interpretation: An Interest Group Model, 86 COLUM. L. REV. 223, 263 (1986) ("[T] commonly held view that prior interpretations of statutes by administrative agencies should be afforded great deference should be reconsidered."). An excellent summary of this discussion is presented in Linda R. Hirshman, Trends in the Law: Postmodern Jurisprudence and the Problem of Administrative Discretion, 82 NW. U. L. REV. 646 (1988). For a discussion of these issues from the perspective of a political scientist, see MOE, supra note 35.

83. 397 U.S. 664 (1970).

84. Id. at 674-675 \& n.3. See also the concurring opinions of Justice Brennan, id. at 690 ("Tax exemptions and general subsidies ... are qualitatively different. Though both provide economic assistance, 
The same distinction was later invoked in Mueller $v$. Allen, ${ }^{85}$ upholding a Minnesota income tax deduction for parental tuition, textbook, and transportation outlays. While the deduction was available to taxpayers with children attending both public and private schools, most of the deductions were taken by parents with offspring in parochial schools. In sustaining the Minnesota deduction against First Amendment challenge, the Mueller Court reiterated that tax provisions stand on stronger constitutional ground than "the direct transmission of assistance" from the public treasury to a religious enterprise. ${ }^{86}$

The Court's First Amendment distinction between tax and direct subsidies has been attacked by many commentators. Professors Surrey and McDaniel, for example, label Walz "naive[]" and "inadequate," an opinion that "will not withstand economic analysis." In this same vein, they lambast Mueller as employing "a false distinction" Lashbrooke similarly bemoans that "[t]he majority in Walz completely misunderstood or deliberately misconstrued the tax expenditure concept when it drew a distinction between a direct money subsidy and a tax exemption." 89 Such criticisms logically flow from the presumed equivalence of tax and direct expenditures.

In contrast, my analysis suggests that, for First Amendment purposes, the dichotomy between tax and direct subsidies to religious organizations is more compelling procedurally than these commentators believe, given the similarity between Establishment Clause concerns and notions of capture. While it is troubling that the Department of Agriculture is influenced by farm interests, ${ }^{90}$ the de facto control of government agencies by religious institutions is

they do so in fundamentally different ways.") (citation omitted), and Justice Harlan, id. at 699 (noting differences between "direct aid" and tax exemptions).

85. 463 U.S. 388 (1983).

86. Id. at 399. The Court's First Amendment distinction between tax and direct expenditures was also central to Comm. for Pub. Educ. \& Religious Liberty v. Nyquist, 413 U.S. 756 (1973). In Nyquist, the Court invalidated on constitutional grounds a New York statute extending to parochial school parents assistance styled as tax benefits. These tax benefits were unrelated to parents' actual tuition outlays and were coordinated with an associated program of direct cash grants to low-income families sending children to private schonls. $I d$. at 790 . The Court viewed the tax program and the cash grant program as related and declared both unconstitutional. It was critical to the Nyquist Court that New York's purported tax program was not a "genuine" tax benefit based on actual tuition outlays but an "arbitrary" use of the tax system, and ultimately, an extension of the direct grant program held unconstitutional. Id. at 790 n.49, 791 .

87. SURREY \& MCDANIEL, supra note 15 , at 132-33.

88. Id. at 136 .

89. Lashbrooke, supra note 15, at 717; see also Joseph M. Kuznicki, Comment, Section 170, Tax Expenditures, and the First Amendment: The Failure of Charitable Religious Contributions for the Return of a Religious Benefit, 61 TEMPLE L. REV. 443, 481 (1988) ("The Court's continued refusal to view tax expenditures in the same light as direct government subsidies is not only irrational, but also perpetuates government entanglement in the sphere of private religious beliefs.") (citation omitted).

90. Again, I emphasize that I use the example of agriculture as illustrative, not exclusive. 
considered especially harmful, so dangerous that it is proscribed constitutionally via the Establishment Clause. ${ }^{11}$

My argument indicates there is less danger of religious interests' capturing tax institutions than direct expenditure agencies. The deduction at issue in Mueller was administered by the Minnesota tax authorities as a part of the state's general tax system. In the legislature's tax-writing committees, supporters of the deduction had to contend with the proponents of other competing tax breaks. Insofar as the politics of Minnesota mirror the politics of the federal government, the Mueller deduction emerged from a more pluralist, more visible, less capturable tax process than would have an equivalent direct expenditure program. Hence, in proceduralist terms, the deduction poses less threat to Establishment Clause values than a comparable direct outlay.

\section{CONCLUSION}

An important contention of the tax expenditure literature is that the specialized institutions that design and administer direct government outlays possess more expertise than the generalist organizations of the tax system. Just as the substantive case against tax subsidies is premised on an idealized notion of direct spending, the procedural indictment of tax preferences is built on an idealized conception of the limited constituency institutions that formulate and implement direct monetary appropriations, a conception that ignores the greater susceptibility to capture of the direct expenditure committees of Congress and the nontax departments of the executive branch.

Because of the more numerous and diverse interests to which they are subject and their greater visibility to the public, the committees and agencies that design and administer tax subsidies are less prone to capture by clientele groups, conform more closely to pluralist norms, and are better positioned to make decisions informed by expertise than their direct expenditure counterparts. The values of the Madisonian/public choice/pluralist tradition of interest group politics will thus lead, in particular cases, to a preference for the more competitive tax organizations.

It is an unexciting defense of political institutions that they are better than is commonly believed and probably the best that can be expected under prevailing circumstances. Madison could not have anticipated the emergence of the federal income tax and its associated organizations as dominant features

91. Of course, this is not the only possible understanding of the Establishment Clause. The separation of church and state may also be understood as strengthening religion by preempting its cooptation by govemment See, e.g., GARRY WILLS, UNDER GOD: RELIGION AND AMERICAN POLITICS 373 (1990). First Amendment concerns can also be defined in exclusively substantive terms, eschewing procedural considerations altogether. 
of American life; he would, however, have understood such a defense of federal tax institutions.

\section{APPENDIX: EMPIRICAL RESULTS}

This Appendix presents the details of the calculations described in the text of the Article. Table 1 presents data comparing levels of tax and direct expenditures provided to four major clientele groups. Many qualifications accompany these calculations. For example, in Table 1, I accept the Treasury's identification of and accounting for particular items of tax preference. To take one case, the tax expenditure budget lists accelerated depreciation ${ }^{92}$ in aggregates and does not allocate such depreciation among farmers, transportation firms or natural resources corporations. Hence, in Table 1 I do not include any amount of accelerated depreciation in the tax benefits accruing to agricultural, transportation or mineral-related taxpayers. ${ }^{93}$ Moreover, the categories used in the federal direct outlay budget do not always correspond to the categories in the tax expenditure budget; in addition, some categories in these documents have changed over time. Thus, I have had to exercise judgment in consolidating particular items to create my four groupings, judgments about which there can be reasonable disagreements. Indeed, the groupings I have used (agriculture, transportation, veterans, and minerals) are neither exhaustive of the special interests served by the direct outlay and tax expenditure systems nor beyond challenge. I could, for example, have disaggregated mineral interests into specific industries, e.g., oil, gas, and uranium.

Proponents of certain direct expenditures would object to my characterization of such outlays as special interest largesse, contending that broader policy considerations justify such expenditures. This also holds true for many of the tax preferences reflected in Table 1: proponents of these preferences could plausibly defend them as advancing the public welfare rather than clientele interests.

In compiling Table 1, I made numerous decisions in a fashion biased against my thesis, i.e., increasing the estimate of tax expenditures while discounting the level of direct outlays. For example, for technical reasons, tax

92. Professor Kahn suggests that accelerated depreciation is not properly considered a tax expenditure. See Kahn, supra note 6, at 12. Since I am skeptical of many of the Treasury's characterizations of particular items as tax subsidies, I am sympathetic to Professor Kahn's position. However, my methodology in developing Table 1 has been to accept the Treasury's characterizations of specific provisions of the Code as tax expenditures.

93. As I discuss infra p.1196, the consistent dominance of direct expenditures over tax subsidies suggests that the assumptions I made in compiling Table 1 did not affect the overall results. For example, as to accelerated depreciation, the tax subsidy for all machinery and equipment in the economy amounted to over twenty-eight billion dollars for 1991. Even if half of this total is arbitrarily allocated to agriculture, tax expenditures for farmers would still only (roughly) equal their direct monetary subsidies. 
expenditure budgets frequently present alternative estimations. In all such cases, I have selected in Table 1 the highest appraisal of the level of tax benefits. Similarly, I have not included the food stamp program within agricultural outlays although some would classify food stamps in significant part as spending to support demand for farm products. ${ }^{94}$ Likewise, I have omitted the large and growing off-budget activities of the federal government, an omission which biases the figures against my thesis by reducing the estimated largesse provided through direct monetary spending. ${ }^{95}$

With all of these qualifications, the dominance of direct over tax expenditures was consistent for all four categories throughout the eleven-year period covered by Table 1 . This pattern was not appreciably affected by such events as the Tax Reform Act of 1986 or the advent and departure of the Reagan Administration. Given the strength and consistency of that dominance, it is unlikely that the choices made in compiling Table 1 affected the overall result, i.e., that largesse for these four interests comes predominantly through direct expenditures obtainable via more capturable institutions rather than through tax benefits which must be secured through more competitive, more visible processes.

94. On the legislative history of the food stamp program, see John Ferejohn, Logrolling in an Institutional Context: A Case Study of Food Stamp Legislation, in CONGRESS AND POLICY CHANGE 223 (Gerald C. Wright, Jr. et al. eds., 1986). Ferejohn portrays the congressional coalition for food stamps as an alliance of urban Democrats interested in expanded welfare programs and rural congressmen seeking commadity supports.

95. Penner, supra note 43 , at 437 (noting the growth of off-budget activity including "credit programs" that "rel[y] heavily on the creation of government sponsored enterprises outside of the budget"); see also WILDAVSKY, supra note 21 , at $9,12,28,121,268$; Stith, supra note 69 , at $605-09$. 
TABLE 1. Direct and Tax Expenditures ${ }^{96}$

(in millions)

\begin{tabular}{|c|c|c|c|c|}
\hline Year & Veterans & Agriculture & Transportation & Minerals \\
\hline 1980 Direct $^{97}$ & $\$ 21,183$ & $\$ 4,762$ & $\$ 25,857$ & $\$ 15,782$ \\
\hline $\operatorname{Tax}^{98}$ & $\$ 1,465$ & $\$ 1,305$ & $\$ 35$ & $\$ 6,720$ \\
\hline 1981 Direct $^{99}$ & $\$ 22,988$ & $\$ 5,572$ & $\$ 28,676$ & $\$ 18,515$ \\
\hline $\operatorname{Tax}^{100}$ & $\$ 1,735$ & $\$ 1,495$ & $\$ 35$ & $\$ 8,555$ \\
\hline 1982 Direct $^{101}$ & $\$ 23,955$ & $\$ 14,875$ & $\$ 26,277$ & $\$ 12,607$ \\
\hline $\operatorname{Tax}^{102}$ & $\$ 2,530$ & $\$ 1,410$ & $\$ 25$ & $\$ 10,885$ \\
\hline 1983 Direct $^{103}$ & $\$ 24,846$ & $\$ 22,206$ & $\$ 25,196$ & $\$ 12,052$ \\
\hline $\operatorname{Tax}^{104}$ & $\$ 2,690$ & $\$ 1,295$ & $\$ 200$ & $\$ 9,073$ \\
\hline 1984 Direct $^{105}$ & $\$ 25,614$ & $\$ 13,613$ & $\$ 27,385$ & $\$ 13,758$ \\
\hline $\operatorname{Tax}^{106}$ & $\$ 2,210$ & $\$ 1,975$ & $\$ 195$ & $\$ 7,193$ \\
\hline 1985 Direct $^{107}$ & $\$ 26,352$ & $\$ 25,565$ & $\$ 29,749$ & $\$ 13,344$ \\
\hline $\operatorname{Tax}^{108}$ & $\$ 2,250$ & $\$ 1,245$ & $\$ 223$ & $\$ 6,873$ \\
\hline \multicolumn{5}{|c|}{ (continued on following page) } \\
\hline
\end{tabular}

96. The figures were compiled from the Office of Management and Budget's (OMB's), SPECIAL ANALYSES, BUDGET OF THE UNITED STATES GOVERNMENT [hereinafter OMB SPECIAL ANALYSES], and its BUDGET OF THE UNITED STATES [hereinafter OMB BUDGET], both of which are published annually. Actual outlays for any given fiscal year [FY] are not available until the second following fiscal year.

97. See OMB SPECIAL ANALYSES, FY 1982, at 32-41 (Special Analysis A).

98. See OMB SPECLAL ANALYSES, FY 1980, at 207-11 (Special Analysis G).

99. See OMB BUDGET, FY 1983, at 9-30 to 9-42 (Summary Tables).

100. See OMB SPECIAL ANALYSES, FY 1983, at 210-15 (Special Analysis G).

101. See OMB SPECIAL ANALYSES, FY 1984, at A-31 to A-41 (Special Analysis A).

102. See OMB SPECIAL ANALYSES, FY 1984, at G-26 to G-28, G-31 to G-33 (Special Analysis G).

103. See OMB SPECIAL ANALYSES, FY 1985, at A-29 to A-38 (Special Analysis A).

104. See OMB SPECIAL ANALYSES, FY 1985, at G-37 to G-42, G-43 to G-48 (Special Analysis G).

105. See OMB SPECIAL ANALYSES, FY 1986, at A-32 to A-43 (Special Analysis A).

106. See OMB SPECIAL ANALYSES, FY 1986, at G-38 to G-42, G-43 to G-47 (Special Analysis G).

107. See OMB SPECIAL ANALYSES, FY 1987, at A-33 to A-44 (Special Analysis A).

108. See OMB SPECIAL ANALYSES, FY 1987, at G-37 to G-41, G-42 to G-46 (Special Analysis G). 
TABLE 1. Direct and Tax Expenditures (continued) (in millions)

\begin{tabular}{|rrrrr|}
\hline Year & Veterans & Agriculture & Transportation & Minerals \\
\hline 1986 Direct ${ }^{109}$ & $\$ 26,356$ & $\$ 31,449$ & $\$ 31,872$ & $\$ 13,761$ \\
Tax $^{110}$ & $\$ 2,295$ & $\$ 1,330$ & $\$ 185$ & $\$ 4,940$ \\
1987 Direct $^{111}$ & $\$ 26,782$ & $\$ 27,356$ & $\$ 30,191$ & $\$ 12,741$ \\
Tax $^{112}$ & $\$ 2,210$ & $\$ 680$ & $\$ 150$ & $\$ 4,665$ \\
1988 Direct $^{113}$ & $\$ 28,674$ & $\$ 22,352$ & $\$ 31,126$ & $\$ 13,615$ \\
Tax $^{114}$ & $\$ 1,980$ & $\$ 858$ & $\$ 165$ & $\$ 3,830$ \\
1989 Direct $^{115}$ & $\$ 30,066$ & $\$ 16,948$ & $\$ 32,555$ & $\$ 15,901$ \\
$\operatorname{Tax}^{116}$ & $\$ 1,945$ & $\$ 790$ & $\$ 160$ & $\$ 4,178$ \\
1990 Direct $^{117}$ & $\$ 28,888$ & $\$ 14,571$ & $\$ 33,524$ & $\$ 16,703$ \\
$\operatorname{Tax}^{118}$ & $\$ 1,915$ & $\$ 560$ & $\$ 165$ & $\$ 4,500$ \\
$1991 \operatorname{Direct}^{119}$ & $\$ 30,349$ & $\$ 15,183$ & $\$ 31,099$ & $\$ 16,446$ \\
$\operatorname{Tax}^{120}$ & $\$ 1,990$ & $\$ 685$ & $\$ 135$ & $\$ 4,418$ \\
\hline
\end{tabular}

109. See OMB SPECIAL ANALYSES, FY 1988, at A-32 to A-43 (Special Analysis A).

110. See OMB SPECial ANALYSES, FY 1988, at G-37 to G-41, G-42 to G-46 (Special Analysis G).

111. See OMB SPEClAL ANALYSES, FY 1989, at A-31 to A-42 (Special Analysis A).

112. See OMB SPECIAL ANALYSES, FY 1989, at G-36 to G-40, G-41 to G-45 (Special Analysis G).

113. See OMB SPECIAL ANALYSES, FY 1990, at A-31 to A-43 (Special Analysis A).

114. See OMB SPECIAL ANALYSES, FY 1990, at G-40 to G-44 (Special Analysis G).

115. See OMB SPECIAL ANALYSES, FY 1990, at A-31 to A-43 (Special Analysis A).

116. See OMB SPECIAL ANALYSES, FY 1990, at G-40 to G-44 (Special Analysis G).

117. See OMB SPECIAL ANALYSES, FY 1990, at A-31 to A-43 (Special Analysis A).

118. See OMB SPECIAL ANALYSES, FY 1990, at G-40 to G-44 (Special Analysis G).

119. See OMB BUdGET, FY 1993, at Appendix One-6 to Appendix One-15.

120. See OMB, BUDGET, FY 1993, at Part Two-25 to Part Two-28. • 
Table 2A measures the Senate Finance Committee's 1989-90 election cycle political action committee (PAC) contributions from agricultural sources; Table $2 \mathrm{~B}$ reflects contributions to the Senate Agriculture Committee from agricultural PAC's during that same period. Table $2 \mathrm{C}$ measures contributions from transportation-related PAC's to members of the House Public Works and Transportation Committee during 1989-90 while Table 2D reports campaign contributions from transportation PAC's to representatives serving on the House Ways and Means panel during the same period. ${ }^{121}$

The compilation of campaign contribution data in Table $2^{122}$ also involved numerous choices. First, I did not include any member serving on both the tax committee and the nontax committee with which it is compared (e.g., a senator on both the Finance and Agriculture Committees) since data about such dual committee members is irrelevant to the thesis that members of nontax committees depend more on particular interests for campaign contributions than do legislators serving on tax-writing committees. ${ }^{123}$ There is, moreover, nothing immutable about the sample I selected or the particular years I examined, i.e., agricultural and transportation contributions for 1989-90. Testing for other years and other interest groups might generate a different pattern of PAC contributions than that embodied in Table $2 .{ }^{124}$

121. Professor Snyder has noted the need for committee-specific inquiry into congressional campaign contributions. James M. Snyder, Jr., Long-Term Investing in Politicians; Or, Give Early, Give Often, 35 congressional committees") (Future research could reveal that some "PACs might be tied to particular research.

122. All data in Tables $2 A$ through Member/Candidate Financial Reports fable 2D were compiled from Lexis, LEGIS library, CNGFIN file,

123. I have classified PAC's as agricultual Senator or Representative.

were made consistently: if a PAC was classified transportation based upon their names. Such judgments Senate Agriculture Committee, it was classified as agricultural when it contributed to a member of the Committee. committees to determine if their Article as an invitation to others to assemble data for other years and is no apparent reason to believe that patterns of campastent with mine. In the absence of such other data, there or that the donations of the agricultural and transportation contributions were distorted in the 1989-90 cycle interest groups. 
TABLE 2A. Senate Finance Committee $(1989-90)^{125}$

\begin{tabular}{|lrr||}
\hline & $\begin{array}{r}\text { PAC Contributions } \\
\text { From Agricultural } \\
\text { Senator }\end{array}$ & $\begin{array}{r}\text { All PAC } \\
\text { Contributions }\end{array}$ \\
\hline Bentsen & $\$ 8,438$ & $\$ 41,523$ \\
Breaux & $\$ 500$ & $\$ 102,350$ \\
Bradley & $\$ 47,425$ & $\$ 1,389,540$ \\
Chafee & $\$ 1,000$ & $\$ 24,390$ \\
Danforth & $\$ 1,000$ & $\$ 20,370$ \\
Durenberger & $\$ 11,150$ & $\$ 147,946$ \\
Hatch & $\$ 882$ & $\$ 24,403$ \\
Heinz & $\$ 0$ & $\$ 22,199$ \\
Mitchell & $\$ 1,000$ & $\$ 11,500$ \\
Moynihan & $\$ 0$ & $\$ 3,094$ \\
Packwood & $\$ 1,000$ & $\$ 4,901$ \\
Riegle & $\$(750)^{126}$ & $\$ 291$ \\
Rockefeller & $\$ 78,935$ & $\$ 1,498,104$ \\
Roth & $\$ 500$ & $\$ 14,580$ \\
Symms & $\$ 32,250$ & $\$ 278,233$ \\
TOTAL & $\$ 183,330$ & $\$ 3,583,424$ \\
\hline
\end{tabular}

Average PAC Contribution:

Average Agricultural PAC Contribution:

Contributions from Agricultural PAC's:
$\$ 238,895$ per Senator

$\$ 12,222$ per Senator

$5.1 \%$

125. Excluding members of Senate Agriculture Committee.

126. A negative number means that a campaign contribution was returned to the donor. 
TABLE 2B. Senate Agriculture Committee (1989-90) ${ }^{127}$

\begin{tabular}{|lrr||}
\hline & $\begin{array}{r}\text { PAC Contributions } \\
\text { From Agricultural }\end{array}$ & $\begin{array}{r}\text { All PAC } \\
\text { Sonator }\end{array}$ \\
Sources & $\$ 128,350$ & $\$ 657,883$ \\
Cochran & $\$ 89,115$ & $\$ 376,454$ \\
Conrad & $\$ 49,440$ & $\$ 226,644$ \\
Fowler & $\$ 150,843$ & $\$ 2,096,649$ \\
Harkin & $\$ 157,817$ & $\$ 1,494,673$ \\
Heflin & $\$ 130,140$ & $\$ 2,004,210$ \\
Helms & $\$ 30,250$ & $\$ 118,700$ \\
Kerrey & $\$ 7,625$ & $\$ 58,125$ \\
Leahy & $\$ 21,350$ & $\$ 49,650$ \\
Lugar & $\$ 171,477$ & $\$ 1,473,803$ \\
McConnell & $\$ 936,407$ & $\$ 8,556,791$ \\
TOTAL & & \\
\hline
\end{tabular}

Average PAC Contribution:

Average Agricultural PAC Contribution:

Contributions from Agricultural PAC's:
$\$ 855,679$ per Senator $\$ 93,640$ per Senator $10.9 \%$

127. Excluding members of Senate Finance Committee. 
TABLE 2C. House Public Works \& Transportation Committee (1989-90)

\begin{tabular}{|c|c|c|}
\hline \multicolumn{3}{|c|}{ PAC Contributions } \\
\hline & portation & All PAC \\
\hline Representative ${ }^{128}$ & Sources & Contributions \\
\hline Anderson & $\$ 86,625$ & $\$ 256,048$ \\
\hline Applegate & $\$ 24,120$ & $\$ 76,856$ \\
\hline Ballenger & $\$ 27,150$ & $\$ 188,039$ \\
\hline Bentley & $\$ 44,850$ & $\$ 201,501$ \\
\hline Boehlert & $\$ 28,700$ & $\$ 122,268$ \\
\hline Borski & $\$ 48,350$ & $\$ 142,475$ \\
\hline Brewster & $\$ 5,300$ & $\$ 145,613$ \\
\hline Clement & $\$ 69,150$ & $\$ 255,385$ \\
\hline Clinger & $\$ 50,669$ & $\$ 193,353$ \\
\hline Collins & $\$ 14,125$ & $\$ 65,900$ \\
\hline Costello & $\$ 51,242$ & $\$ 238,648$ \\
\hline $\operatorname{Cox}$ & $\$ 26,950$ & $\$ 185,958$ \\
\hline Cramer & $\$ 20,500$ & $\$ 208,183$ \\
\hline de Lugo & $\$ 3,900$ & $\$ 7,150$ \\
\hline DeLauro & $\$ 37,350$ & $\$ 325,563$ \\
\hline DeFazio & $\$ 45,450$ & $\$ 170,520$ \\
\hline Duncan & $\$ 41,300$ & $\$ 166,614$ \\
\hline Emerson & $\$ 38,500$ & $\$ 262,050$ \\
\hline Geren & $\$ 94,420$ & $\$ 681,188$ \\
\hline Gillmor & $\$ 15,200$ & $\$ 240,972$ \\
\hline Hammerschmidt & $\$ 69,000$ & $\$ 169,060$ \\
\hline Hancock & $\$ 31,150$ & $\$ 126,057$ \\
\hline Hayes & $\$ 43,500$ & $\$ 199,711$ \\
\hline Hobson & $\$ 18,050$ & $\$ 172,725$ \\
\hline Horn & $\$ 24,750$ & $\$ 117,508$ \\
\hline Inhofe & $\$ 61,566$ & $\$ 405,971$ \\
\hline Jones & $\$ 55,450$ & $\$ 557,511$ \\
\hline Kolter & $\$ 45,050$ & $\$ 157,056$ \\
\hline Laughlin & $\$ 97,151$ & $\$ 449,452$ \\
\hline Lewis & $\$ 31,150$ & $\$ 194,989$ \\
\hline Lipinski & $\$ 44,800$ & $\$ 123,549$ \\
\hline Mineta & $\$ 70,806$ & $\$ 377,802$ \\
\hline Molinari & $\$ 25,950$ & $\$ 274,163$ \\
\hline Nichols & $\$ 4,500$ & $\$ 69,024$ \\
\hline Nowak & $\$ 27,650$ & $\$ 98,351$ \\
\hline Oberstar & $\$ 98,300$ & $\$ 269,102$ \\
\hline
\end{tabular}

128. Eleanor Holmes Norton, the District of Columbia delegate, has no vote and was therefore omitted from the survey. 
Table 2C. House Public Works \& Transportation Committee (1989-90) (continued)

\begin{tabular}{|c|c|c|}
\hline & $\begin{array}{l}\text { ontributions } \\
\text { ansportation }\end{array}$ & All PAC \\
\hline Representative & Sources & Contributions \\
\hline Packard & $\$ 31,935$ & $\$ 99,096$ \\
\hline Pallone & $\$ 41,575$ & $\$ 389,118$ \\
\hline Parker & $\$ 40,154$ & $\$ 286,957$ \\
\hline Payne & $\$ 39,150$ & $\$ 201,839$ \\
\hline Peterson & $\$ 17,500$ & $\$ 82,700$ \\
\hline Petri & $\$ 18,120$ & $\$ 93,454$ \\
\hline Poshard & $\$ 0$ & $\$ 7,445$ \\
\hline Rahall & $\$ 75,850$ & $\$ 301,481$ \\
\hline Riggs & $\$ 0$ & $\$ 1,000$ \\
\hline Roe & $\$ 102,500$ & $\$ 316,967$ \\
\hline Sangmeister & $\$ 36,400$ & $\$ 388,522$ \\
\hline Savage & $\$ 21,550$ & $\$ 64,463$ \\
\hline Shuster & $\$ 107,848$ & $\$ 192,033$ \\
\hline Swett & $\$ 14,300$ & $\$ 145,415$ \\
\hline Taylor & $\$ 15,500$ & $\$ 194,255$ \\
\hline Traficant & $\$ 15,775$ & $\$ 54,680$ \\
\hline Upton & $\$ 30,913$ & $\$ 154,701$ \\
\hline Valentine & $\$ 33,174$ & $\$ 134,004$ \\
\hline Visclosky & $\$ 42,250$ & $\$ 171,151$ \\
\hline Zeliff & $\$ 1,500$ & $\$ 86,550$ \\
\hline TOTALS & $\$ 2,208,668$ & $\$ 11,262,146$ \\
\hline
\end{tabular}

Average PAC Contribution:

$\$ 201,110$ per Rep.

Average Transportation PAC Contribution: $\$ 39,440$ per Rep.

Contributions from Transportation PAC's: $\quad 19.6 \%$ 
TABLE 2D. House Ways \& Means Committee (1989-90)

\begin{tabular}{|c|c|c|}
\hline & $\begin{array}{l}\text { tributions } \\
\text { portation }\end{array}$ & All PAC \\
\hline Representative & & \\
\hline Andrews & $\$ 22,650$ & $\$ 300,698$ \\
\hline Anthony & $\$ 28,820$ & $\$ 381,004$ \\
\hline Archer & $\$ 0$ & $\$ 6,545$ \\
\hline Bunning & $\$ 29,450$ & $\$ 222,493$ \\
\hline Cardin & $\$ 27,650$ & $\$ 324,592$ \\
\hline Chandler & $\$ 35,150$ & $\$ 269,649$ \\
\hline Coyne & $\$ 13,875$ & $\$ 129,621$ \\
\hline Crane & $\$ 0$ & $\$(817)$ \\
\hline Donnelly & $\$ 14,750$ & $\$ 170,000$ \\
\hline Dorgan & $\$ 40,500$ & $\$ 436,859$ \\
\hline Downey & $\$ 27,900$ & $\$ 330,111$ \\
\hline Ford & $\$ 38,890$ & $\$ 175,509$ \\
\hline Gibbons & $\$ 35,750$ & $\$ 314,300$ \\
\hline Gradison & $\$ 0$ & $\$ 3,880$ \\
\hline Grandy & $\$ 20,250$ & $\$ 262,278$ \\
\hline Guarini & $\$ 36,500$ & $\$ 321,438$ \\
\hline Jacobs & $\$ 0$ & $\$ 890$ \\
\hline Jenkins & $\$ 11,100$ & $\$ 209,299$ \\
\hline Johnson & $\$ 21,850$ & $\$ 245,822$ \\
\hline Kennelly & $\$ 21,354$ & $\$ 278,002$ \\
\hline Levin & $\$ 26,850$ & $\$ 257,647$ \\
\hline Matsui & $\$ 44,482$ & $\$ 573,902$ \\
\hline McDermott & $\$ 32,150$ & $\$ 201,156$ \\
\hline McGrath & $\$ 40,620$ & $\$ 317,916$ \\
\hline Moody & $\$ 35,050$ & $\$ 404,342$ \\
\hline Pease & $\$ 27,000$ & $\$ 195,079$ \\
\hline Pickle & $\$ 23,250$ & $\$ 245,000$ \\
\hline Rangel & $\$ 42,450$ & $\$ 359,060$ \\
\hline Rostenkowski & $\$ 39,000$ & $\$ 219,972$ \\
\hline Russo & $\$ 47,975$ & $\$ 384,007$ \\
\hline Schulze & $\$ 35,000$ & $\$ 370,488$ \\
\hline Shaw & $\$ 27,800$ & $\$ 229,598$ \\
\hline Stark & $\$ 28,750$ & $\$ 345,322$ \\
\hline Sundquist & $\$ 39,750$ & $\$ 335,350$ \\
\hline Thomas & $\$ 12,000$ & $\$ 253,139$ \\
\hline Vander Jagt & $\$ 45,830$ & $\$ 274,770$ \\
\hline TOTALS & $\$ 974,396$ & $\$ 9,348,921$ \\
\hline
\end{tabular}

Average PAC Contribution:

Average Transportation PAC contribution: Contributions from Transportation PAC's:
$\$ 259,692$ per Rep. $\$ 27,066$ per Rep. $10.4 \%$ 
Finally, using Nexis files, ${ }^{129}$ I have estimated ${ }^{130}$ in Table $3 \mathrm{~A}$, for a sample of farm, petroleum, and transportation trade publications, the number of stories appearing in each publication about one or both of the congressional tax committees. I have also determined for each publication the approximate number of articles about the appropriate direct expenditure committees of Congress for the industry covered by that publication. ${ }^{131}$ In Table 3B, I have similarly estimated for three large newspapers of general circulation ${ }^{132}$ both the number of articles about Congress' tax committees and the number of stories about the six nontax committees affecting the farm, mineral and transportation industries. ${ }^{133}$ The final column of Table 3B reflects, for each general newspaper, the ratio of its total articles about all six direct expenditure committees to its articles about the two tax panels.

129. My research was done on April 18, 1992 and April 19, 1992 and thus reflects the Nexis files as they existed on those two dates. My specific search terms were as follows: (senate w/5 committee and senate $w / 5$ commerce) or (house w/5 committee and house w/5 transport); (ways w/1 means) or (finance w/l committee); (senate $w / 5$ committee and senate $w / 5$ commerce) or (house public works); (energy w/2 natural resources) or (energy w/3 committee and commerce w/ 1 committee); agricultur! committee.

130. As to the publications with relatively small samples (Dairy Foods, Coal, Coal Week, National Petroleum News and Transportation and Distribution), I read each article identified by my search to confirm that it referred either to the tax committees of Congress or to the appropriate nontax committees for the industry covered by the publication. As to the other publications surveyed (Oil and Gas Journal and Aviation Daily), the electronic search produced too many items for me to read each individually. Consequently, I read the first fifty articles revealed by each search to determine the percentage of false positives, e.g., references to a state senate finance committee rather than the U.S. Senate Finance Committee. I then applied the resulting ratio to the total number of items produced by the search. For example, the search for "Ways and Means" and "Finance Committee" produced 429 total items in Oil and Gas Journal. Of the first fifty of these, three were not reporting about the federal Senate or House taxwriting committee while the other forty-seven were referring to one or the other (or both) of these panels. Consequently, I have estimated the total references to the federal tax committees for Oil and Gas Journal to be 404 , i.e., $429 \times 47 / 50$.

131. Thus, for Dairy Foods, the nontax committees I measured were the Senate and House agriculture committees. For Coal, Coal Week, National Petroleum News, and Oil and Gas Journal, I identified as the appropriate direct expenditure panels the Senate Committee on Energy and Natural Resources and the House Committee on Energy and Commerce. For Aviation Daily and Transportation and Distribution, I used as the direct expenditure committees affecting the aviation and trucking industries the Senate Committee on Commerce, Science and Technology and the House Committee on Public Works and Transportation.

132. The New York Times, The Los Angeles Times and The Chicago Tribune.

133. See supra note 131 . 
TABle 3A. Trade Press

\begin{tabular}{||lrr||}
\hline & & $\begin{array}{r}\text { Articles about } \\
\text { Publication }\end{array}$ \\
Darticles about & Direct Expenditure \\
Dairy Foods & 1 & 7 \\
Coal Week & 74 & 163 \\
Coal & 16 & 44 \\
Trans. \& Distribution & 4 & 13 \\
Aviation Daily & 104 & 266 \\
Oil and Gas Journal & 404 & 121 \\
Nat'l Petroleum News & 13 & 4 \\
\hline \hline
\end{tabular}

TABLE 3B. General Press ${ }^{134}$

\begin{tabular}{|c|c|c|c|}
\hline Articles On & N.Y. Times & L.A. Times & Chicago Tribune \\
\hline Agriculture Comm. ${ }^{135}$ & 821 & 268 & 547 \\
\hline Minerals Comm. ${ }^{136}$ & 1,536 & 557 & 258 \\
\hline Transportation Comm. ${ }^{137}$ & 924 & 143 & 221 \\
\hline All Nontax Comm. ${ }^{138}$ & 3,281 & 968 & 1,026 \\
\hline All Tax Comm. ${ }^{139}$ & 5,801 & 1,356 & 1,312 \\
\hline Ratio (Nontax:Tax) ) $^{140}$ & $1: 1.77$ & $1: 1.40$ & $1: 1.28$ \\
\hline
\end{tabular}

Some limitations about this data must be acknowledged. My results may be affected by the particular sample of ten publications (three general, seven trade) which I have constructed and reported in Table 3. Several of the magazines in my sample have come into the Nexis system relatively recently and therefore have comparatively few observations. ${ }^{141}$ The publications covered by Nexis may be unrepresentative of the publications omitted by Nexis. Moreover, the information in Table 3 is purely quantitative, measuring

134. Because of the large number of items identified by my search, all of the estimates in Table $3 B$ were developed using the ratio method discussed stupra note 130 .

135. That is, total references to the House and Senate agriculture committees.

136. That is, the Senate Energy and Natural Resources Committee and the House Energy and Commerce Committee.

137. That is, the Senate Committee on Commerce, Science and Transportation and the House Public Works and Transportation Committee.

138. That is, the total of the three preceding lines.

139. That is, the total of all articles referring to the House Ways and Means Committee, the Senate Finance Committee or both.

140. That is, the ratio of all articles about all six direct expenditure committees to the number of articles about the tax committees.

141. Dairy Foods, for example, contained only eight references in total to Congress' tax-writing and agriculture committees. 
the number of articles referring to each particular committee of Congress. A different view might conceivably emerge from the measurement of the qualitative disparities in press coverage of Congress' tax and nontax committees. Finally, some of the articles reported in Table 3 about the Ways and Means and Finance panels refer to the nontax jurisdictions of these bodies while some of the articles about the nontax committees refer to committee jurisdictions unrelated to the industries I am examining, i.e., agriculture, transportation and minerals. ${ }^{142}$

142. For example, the House Ways and Means Committee has jurisdiction over many trade issues. Thus, some of the articles reflected in Table 3 refer to this jurisdiction rather than Ways and Means' authority over taxes. Similarly, the House Public Works and Transportation Committee has authority over many public works projects which are not transportation-related. 
